Tamara Slišković* Josip Tica **
JEL Classification R21, R31, O18 Izvorni znanstveni rad https://doi.org/10.32910/ep.70.5.1

\title{
ZNAČAJ UDALJENOSTI U HEDONIČKOM MODELU ODREĐIVANJA CIJENA STANOVA U ZAGREBU
}

Cilj ovog rada je procjena učinaka udaljenosti od središta grada na cijene stambenih nekretnina u Gradu Zagrebu unutar hedoničkog modela. Model prezentiran u radu je prvi u hrvatskoj literaturi hedoničkog modeliranja koji istovremeno obuhvaća varijable udaljenosti, druge lokacijske varijable, interne karakteristike nekretnina i efekt vremena prodaje stana na zagrebačkom tržištu. Razlika u odnosu na dosadašnju praksu u Hrvatskoj se sastoji u tome što se do sada lokacija stambene nekretnine uobičajeno opisivala širim područjima poput gradskih četvrti. Procjena efekata udaljenosti $i$ drugih lokacijskih varijabli je provedena unutar hedoničkih modela traženih i postignutih cijena stambenih nekretnina, odnosno stanova. Dokazano je kako su udaljenost od središta grada i varijable kojima se opisuje smještaj nekretnine na pojedinim stranama svijeta statistički značajne za objašnjavanje traženih i stvarnih cijena stanova u Zagrebu. Nadalje, njihovo uključivanje u hedonički model poboljšava njegovu prilagođenost stvarnim podacima u odnosu na dosadašnje modele izrađene za hrvatska stambena tržišta.

Ključne riječi: udaljenost, središte grada, hedonička procjena, cijene stanova

${ }^{*}$ Doc. dr. sc. T. Slišković, docentica, Sveučilište u Zagrebu, Ekonomski fakultet (e-mail: tamara.sliskovic@efzg.hr).

** Prof. dr. sc. J. Tica, redoviti profesor, Sveučilište u Zagrebu, Ekonomski fakultet (e-mail: jtica@efzg.hr).

Ovaj rad je sufinancirala Hrvatska zaklada za znanost projektom 7031. Zahvaljujemo se Hrvatskoj zakladi za znanost i Interventnom fondu za potporu doktorandima Sveučilišta u Zagrebu na pomoći pri financiranju ovog istraživanja; Burzi nekretnina za izgradnju i isporuku potrebne baze podataka i informatičkoj tvrtki MIREO d.d. na doniranom vremenu i ustupljenim softverskim rješenjima za konstruiranje varijable udaljenosti od središta grada, koja je ključna varijabla istraživanja.

Rad je primljen u uredništvo 11.06.2018. godine, a prihvaćen je za objavu 03.09.2018. godine. 


\section{UVOD}

Cilj ovoga rada je analizirati utjecaj udaljenosti od centra grada na tražene i postignute cijene stambenih nekretnina na zagrebačkom tržištu nekretnina. Udaljenost, odnosno troškovi transporta (dnevnih migracija) predstavljaju fundamentalnu eksplanatornu varijablu u teoretskim modelima ekonomike prostora (Fujita, Krugman i Venables, 1999). Unatoč tome, utjecaj udaljenosti je u hrvatskoj empiriji i praksi sustavno zanemarivan, te je vrlo često zbog nedostupnosti podataka supstituiran pokazateljima naselja, odnosno kvarta u znanstvenim i stručnim analizama (Centar Nekretnina, 2015; Kunovac, Đozović, Lukinić i Pufnik., 2008).

Najvažniji doprinos ovoga rada je integracija mjere udaljenosti unutar do sada primjenjivanog hedoničkog modela u Hrvatskoj. Utjecaj udaljenosti na cijene stanova je procijenjen pomoću metode najmanjih kvadrata, a statistička signifikantnost skupova varijabli udaljenosti je testirana Wald testom. Problem (ne)dostupnosti podataka o udaljenosti je riješen pomoću softverskog rješenja i doniranog serverskog vremena tvrtke MIREO d.d, a sama analiza je napravljena na podacima Burze nekretnina (2015) za tražene i postignute cijene.

U odnosu na postojeća istraživanja koja su uključivala varijablu udaljenosti u modele procjene vrijednosti stanova (Slišković i Tica, 2016), ključna razlika ovoga rada se očituje u obuhvaćanju većeg skupa eksplanatornih varijabli. U analizi se koriste podaci o kvalitativnim karakteristikama stanova koji nisu bili dostupni u bazi Centra nekretnina (2010) na kojoj je rađeno istraživanje Slišković i Tice (2016). Uporaba baza podataka Burze nekretnina (2015) je dodatno omogućila procjenu modela postignutih cijena.

Rezultati istraživanja ukazuju kako je utjecaj udaljenosti od centra grada statistički različit od nule, te da se koeficijenti utjecaja udaljenosti statistički razlikuju jedni od drugih s obzirom na stranu svijeta na kojoj mjerimo udaljenost od gradskog središta u Zagrebu.

Rad je podijeljen u pet poglavlja. Nakon uvoda, u drugom poglavlju se prezentira hedonička metoda i teoretska podloga za uključivanje varijable udaljenosti u hedonički model procjene cijena stanova. U trećem poglavlju se opisuju korišteni podaci, njihovi izvori i metode provođenja istraživanja. Četvrto poglavlje prezentira rezultate procjene hedoničkih modela traženih i postignutih cijena stanova u Gradu Zagrebu, a u petom poglavlju se sumiraju dobiveni zaključci. 
T. SLIŠKOVIĆ, J. TICA: Značaj udaljenosti u hedonističkom modelu određivanja cijena stanova u Zagrebu

EKONOMSKI PREGLED, 70 (5) 677-705 (2019)

\section{HEDONIČKO MODELIRANJE CIJENA STAMBENOG PROSTORA}

Stambene nekretnine su heterogen proizvod, zbog čega je istraživački interes često usmjeren na utvrđivanje odrednica njihovih cijena. Središnje mjesto pri procjenama na lokalnim tržištima ima hedonički pristup. Jedno od njegovih ključnih ograničenja predstavlja dostupnost podataka o obiljě̌jima stanova. Naime, tehnički se ovom metodom nastoji obuhvatiti što veći broj lokacijskih i internih karakteristika nekretnina. Potom se unutar postavljenog modela procjenjuje doprinos svake pojedine karakteristike u objašnjavanju devijacija u cijenama između različitih stambenih jedinica. Konstantnim unaprjeđenjem tog pristupa, a posebice izgradnjom potpunijih baza podataka nastoji se pospješiti efikasnost postupaka masovnih procjena nekretnina.

Upravo se, zbog problema dostupnosti podataka, u Hrvatskoj razvila praksa da se kvaliteta lokacije aproksimira širim prostornim područjima, primjerice naseljima ili kvartovima. Kako administrativne granice prvenstveno aproksimiraju utjecaj kvalitete infrastrukture nekog naselja na cijene stanova, postojala je potreba da se izgradi baza podataka na temelju koje će se moći odvojeno kvantificirati utjecaj udaljenosti na cijene stambenog prostora, za što postoji snažno uporište u teoriji urbane ekonomike.

\subsection{Teorijski aspekti povezanosti lokacije i cijena stambenog prostora}

U ekonomskoj teoriji lokacija je ključan čimbenik za objašnjavanje rasporeda ekonomskih aktivnosti u prostoru i razlika u cijenama nekretnina. Jedan od temeljnih mehanizama u urbanoj ekonomici je funkcija ponuđene rente (engl. bid-rent function) kojom se povezuju udaljenosti od središta grada ili gradske zaposlenosti i cijene nekretnina. Začetnikom teorije povezanosti rente i udaljenosti se smatra njemački ekonomist Von Thünen (1826). Temelj njegove teorije predstavljaju transportni troškovi, koji pozitivno koreliraju s udaljenošću te su na taj način glavna odrednica cijena zemljišta na različitim lokacijama. Koncept funkcija ponuđene rente dalje razvija Alonso (1964) koji ih smješta u urbani kontekst. Muth (1969) i Mills (1972) razvijaju specifičan oblik funkcije ponuđene rente - funkciju cijena stanovanja koja je usmjerena na cijene stambenog prostora, umjesto na rezidencijalno zemljište. Svi od navedenih autora su se vodili pretpostavkom da je središte grada centralno i najvažnije područje gradske zaposlenosti. Iz tog razloga upravo ono predstavlja referentnu zonu čija blizina određuje cijene.

U istraživačkoj praksi se često umjesto prostorne udaljenosti procjenjuje efekt vremenske udaljenosti na cijene stambenog prostora. Pokazalo se kako je 
vrijeme putovanja različitim oblicima prijevoza visoko korelirano s ukupnim troškom dnevnih migracija. Iz tog razloga se često vrijeme putovanja koristi kao proxy varijabla za ukupni trošak dnevnih migracija, kao što je u radovima autora Dubin (1991), Giuliano i Small (1991), Small i Song (1992), Fina (2000), Yiu i Tam (2004) te Ottensmann, Payton i Man (2008). Dosadašnja istraživanja su općenito pokazala kako je, u monocentričnim gradovima, varijabla udaljenosti negativno povezana s cijenama stambenog prostora. No, ukoliko u urbanoj jedinici ne postoji samo jedan, već više centara zaposlenosti, tada parametar uz varijablu udaljenosti može biti pozitivan, ili pak negativan, ali statistički neznačajan što je slučaj kod autora Heikkila et al. (1989) i Dubin i Sung (1987).

Iz svega navedenog je moguće zaključiti kako u teoriji i empiriji postoji snažno uporište za tvrdnju kako udaljenost od središta grada ili cent(a)ra zaposlenosti jest vrlo značajan faktor kojim se, barem jednim dijelom, mogu objasniti razlike u cijenama stambenog prostora. Stoga hedonički modeli određivanja cijena stambenog prostora, sukladno teoretskim modelima, osim vremena transakcije i internih karakteristika moraju obuhvatiti i pokazatelje udaljenosti i dostupnosti gradskog središta i/ili centara zaposlenosti. U nekoliko istraživanja u Hrvatskoj su primijenjeni hedonički modeli na primjerima različitih stambenih tržišta, no niti u jednom od njih do sada nije uključena udaljenost od navedenih točaka interesa, već je lokacija aproksimirana određenim širim definicijama.

\subsection{Dosadašnja praksa određivanja cijena stambenog prostora hedoničkim pristupom u Hrvatskoj}

Kao najveća prednost hedoničke metode često se ističe njezina jednostavnost. $\mathrm{S}$ tehničke strane, modeliranje cijena stambenih nekretnina se svodi na regresiranje cijene jedinice stambenog prostora na vektor njegovih karakteristika. No, pojedini autori su ukazali i na nedostatke primjene navedene metode u svrhu masovne procjene nekretnina. Primjerice, ponekad se postavlja pitanje odabira funkcionalnog oblika modela. Nadalje, javlja se problem ispravne specifikacije modela i izostavljanja potencijalno značajnih varijabli iz skupa karakteristika. Potonje je često posljedica nedostupnosti, odnosno nepostojanja potrebnih podataka čak i na zemljopisno malim tržištima.

Općenito, nedostaci hedoničke metode primarno proizlaze iz prirode podataka koji su temelj za provođenje analize. Obzirom na neodvojivost stambene nekretnine od njene lokacije, podaci o njima neizbježno sadrže i prostornu komponentu te se kao moguće poteškoće navode prostorna autokorelacija i prostorna heterogenost. Zbog potencijalnih pristranih procjena, umjesto hedoničke, pojedini autori predlažu metode prostorne ekonometrije kao primjerenije rješenje (Anselin i Le 
Gallo, 2006; Walacik, Cellmer i Źróbek, 2013). Tu spadaju neparametarski modeli, poput lokalno i geografski ponderiranih regresija (McMillen i Redfearn, 2010) te njihovog proširenja vremenskom komponentom (Huang, Wu i Barry, 2010), ili pak modeli neuralnih mreža (Peterson i Flanagan, 2009). Ipak, smatra se da prednosti hedoničke metode nadilaze njene nedostatke, što ju ipak čini korisnim alatom za procjenu cijena nekretnina (Worzala, Lenk i Silva , 1995; Hill, 2011).

Obzirom na prednosti i nedostatke, može se utvrditi kako sve slabosti hedoničkog modeliranja predstavljaju prostor za daljnje unaprjeđenje tih metoda. U hrvatskoj istraživačkoj praksi se taj prostor ogleda primarno u izgradnji potpunijih baza podataka, čime bi se u budućnosti otvorila mogućnost i za primjenu nekih od navedenih složenijih metoda procjene. Pri tome se posebno ističe mogućnost preciznijeg definiranja lokacije. Naime, u većini dosadašnjih malobrojnih istraživanja koja koriste navedeni pristup je lokacija aproksimirana regijom ili gradskim četvrtima. U trenutku izrade ovog istraživanja, postojale su procjene funkcija cijena stanovanja na pojedinim stambenim tržištima, kao i procjene efekata različitih mjera udaljenosti i dostupnosti središta grada na cijene stambenog prostora, ali ne postoji niti jedan potpuni hedonički model koji bi, istovremeno uz interne karakteristike nekretnine i lokaciju definiranu na širi način obuhvaćao i efekte preciznije definirane lokacije.

Među prvima su u Hrvatskoj hedoničke modele koristile Botrić i Kordej De Villa (2005). Njihov model je, uz pojedine interne karakteristike, uključivao lokaciju izraženu pripadnošću stambene nekretnine pojedinoj regiji, koja je u model uključena kao binarna varijabla.

Posebno značajno mjesto u domaćoj literaturi u ovoj sferi istraživanja pripada radu Kunovca i sur. (2008) na temelju kojeg je izrađen hedonistički indeks cijena nekretnina (HICN) koji je u sklopu redovne statistike na kvartalnoj i godišnjoj razini objavljivala Hrvatska narodna banka sve do polovice 2015. godine. Obzirom da je taj indeks, sve do nedavno, predstavljao jedini indeks cijena nekretnina u Hrvatskoj koji je korigiran za kvalitetu ${ }^{1}$, široko je korišten u brojnim domaćim stručnim i znanstvenim radovima koji su nastali u posljednjih 10 godina, iz čega proizlazi i neosporan aplikativni doprinos navedenog istraživanja.

Inicijalni model procjene traženih, ali i postignutih cijena stambenog prostora Kunovca i sur. (2008) je procijenjen na temelju podataka Burze nekretnina. Nezavisne varijable u njihovom modelu obuhvaćaju kvalitativna obilježja nekretnina, vrijeme prodaje nekretnine te geografsko-lokacijska obilježja. Ovdje je važno naglasiti kako je i u ovom slučaju lokacija definirana na širi način i aproksimirana pripadnošću određenoj regiji, županiji, mjestu ili dijelu grada te je, kao i većina internih karakteristika, u model uključena kao binarna varijabla. Dakle, niti u ovom

1 Od siječnja 2016. godine Državni zavod za statistiku objavljuje indeks cijena stambenih nekretnina koji se također temelji na primjeni hedoničkih regresija. 
modelu nisu obuhvaćeni efekti preciznije definirane lokacije mjerene udaljenošću od središta grada ili ekonomskog interesa.

Procjenu funkcija cijena stambenog prostora na primjeru zagrebačkog tržišta stambenog prostora daje Boras (2013). Istraživanje se isključivo odnosi na povezanost različitih mjera udaljenosti od središta grada s cijenama stambenog prostora i ne uključuje efekte internih karakteristika nekretnina. Iz tog se razloga ne može svrstati među radove koji se bave hedoničkim modeliranjem cijena na hrvatskim tržištima, kao niti kasniji rad Slišković i Tice (2016). Unutar njega je simultano procijenjen utjecaj udaljenosti od gradskog središta i pripadnosti pojedinim gradskim četvrtima i zonama, no također je izostavljen učinak internih karakteristika nekretnina na njihovu cijenu (osim efekta površine). Model je specificiran kao standardni hedonički model u kojem je zavisna varijabla prirodni logaritam tražene cijene kvadratnog metra stambenog prostora, dok popis nezavisnih varijabli obuhvaća veći broj lokacijskih varijabli, uključujući udaljenost od središta grada i pripadnost nekretnine pojedinoj gradskoj zoni i strani svijeta, površinu stambene jedinice te dvije indikatorske varijable koje odražavaju godinu u kojoj je stambena nekretnina ponuđena na tržištu. Slabošću ovog istraživanja se, osim nepostojanja internih karakteristika među nezavisnim varijablama smatra i to što je izrađeno na temelju baze podataka Centra nekretnina (2010), koja je sadržavala isključivo podatke o traženim cijenama koje se ne smatraju najrealnijim pokazateljem stanja na tržištu nekretnina.

Ovim istraživanjem se nastoje popuniti svi navedeni propusti. Konkretno, uz istovremenu procjenu efekata udaljenosti i šire definirane lokacije obuhvatit će se i efekti koje interne karakteristike nekretnina, kao i druge varijable koje su se u prethodnim istraživanjima pokazale kao statistički značajne (primjerice, razdoblje u kojem je nekretnina prodana), imaju na visinu traženih i postignutih cijena na zagrebačkom tržištu stambenog prostora.

\section{PODACI I METODOLOGIJA}

\subsection{Podaci}

Osnovni izvor podataka na temelju kojih se procjenjuje hedonički model za zagrebačko stambeno tržište je interna baza koja je kupljena od Burze nekretnina. Time je omogućeno diferenciranje od rada Slišković i Tice (2016), dok je istovremeno omogućena usporedba dobivenih rezultata s onima iz rada Kunovca i sur. (2008).

U svom originalnom obliku baza Burze nekretnina sadržava najveći broj varijabli koje su uključene u model. Tu spadaju podaci o postignutim i traženim ci- 
jenama stanova koji su prodani u razdoblju 2002.-2013. godine na području Grada Zagreba, kao i podaci o pojedinim internim i lokacijskim karakteristikama stambenih nekretnina obuhvaćenih bazom. Interne (kvalitativne) karakteristike obuhvaćaju podatke o površini, broju soba, katu na kojem se stan nalazi, postojanju balkona, lođe, plina i lifta ${ }^{2}$. Također su dostupne i informacije o godini izgradnje te datumu prodaje stana. Glede lokacijskih karakteristika, navedene su gradske zone (gradske četvrti), a za preciznije definiranje lokacije su navedene i ulice u kojima su nalaze nekretnine.

Obzirom na osjetljivost (privatnost) podataka, podaci o ulicama u kojima su stanovi smješteni predstavljaju najprecizniji mogući pokazatelj njihove lokacije. Upravo ti podaci, kojima se preciznije definira lokacija stambene jedinice su visoko vrijedni za provedbu ovog istraživanja, obzirom da su na temelju njih izračunate udaljenosti od centra grada, koje su osnova za izradu novog hedoničkog modela koji se može diferencirati od već postojećih, sličnih modela koji se koriste u praksi, a ne obuhvaćaju varijable udaljenosti.

Izvor podataka za varijablu udaljenosti je navigacijski sustav informatičke tvrtke MIREO d.d.. Za formiranje varijable primarno je provedeno geo-kodiranje postojećih podataka o ulicama u kojima se stanovi nalaze, i to pomoću računalnog koda i serverskog vremena koje je navedena tvrtka donirala. Izlazni podaci geo-kodiranja (zemljopisna širina i dužina) su potom preračunati u udaljenost od središta grada, koje je aproksimirano zemljopisnom širinom i dužinom Trga bana Josipa Jelačića. Dakle, izračun udaljenosti je proveden pod pretpostavkom monocentričnosti Grada Zagreba.

Tablica izlaznih rezultata obuhvaća podatke o prostornoj (u metrima) i vremenskoj (u sekundama) udaljenosti od središta grada. Dobiveni podaci su, radi lakše interpretacije modificirani na način da je prostorna udaljenost izražena u kilometrima, a vremenska u minutama. Sveukupno izlazni podaci obuhvaćaju četiri modaliteta udaljenosti: prostorna udaljenost mjereno automobilom i pješice te vremenska udaljenost mjerena automobilom i pješice. Svaki od modaliteta udaljenosti predstavlja najkraću moguću udaljenost koju je ponudio navigacijski sustav.

Unutar ovog istraživanja, zbog opsežnosti rezultata, koristit će se samo jedan modalitet udaljenosti - prostorna udaljenost, u kilometrima, mjerena automobilom ${ }^{3}$.

2 Također su u bazi dostupni podaci i o vrsti grijanja, katnosti zgrade, postojanu telefona i garaže, no oni su za sve nekretnine dostupni samo u razdoblju nakon 2006. godine. Obzirom da je jedna od pretpostavki autora bila da je vrijeme prodaje značajan čimbenik u modeliranju cijena, navedene interne karakteristike su izostavljene iz analize kako se dostupna vremenska dimenzija ne bi skraćivala.

3 Rezultati procjena temeljeni na drugim modalitetima su doveli do identičnih zaključaka koji su prezentirani u ovom radu, te su dostupni na upit autorima ovog rada. 
Nakon užeg definiranja lokacije, šira definicija podrazumijeva smještaj nekretnina u određenim gradskim četvrtima prema podacima koji su dostupni u bazi Burze nekretnina. Konačno, još jedno lokacijsko obilježje koje se koristi unutar postavljenog hedoničkog modela je pripadnost stambene jedinice određenoj strani svijeta. Temelj za formiranje takve varijable su radovi Boras (2012, 2013) i Slišković i Tica (2016) u kojima je pokazano da udaljenost od centra grada ima značajne učinke na formiranje traženih cijena stambenog prostora, ali i da postoje razlike između tih efekata s obzirom na smjer udaljavanja od središta grada. Stoga je područje Grada Zagreba podijeljeno na 8 strana svijeta prema kriterijima koji su korišteni u navedenim istraživanjima.

Vremenska dimenzija je u model uvedena uključivanjem podataka o godini u kojoj je stambena nekretnina prodana na tržištu. Nedostatak vezan uz ovu varijablu se odnosi na izostavljanje 2009. godine iz analize. Naime, Burza nekretnina ne raspolaže podacima o adresama (ulicama) stanova koji su na tržištu prodani tijekom 2009. godine, stoga te informacije nisu isporučene u kupljenoj bazi. Kako je podatak o adresi bio ključan za računanje udaljenosti od centra grada, za stanove prodane u navedenoj godini nije bilo moguće generirati te podatke, pa su stoga isključeni iz analize.

U konačnoj bazi podataka koja je konstruirana za potrebe ovog istraživanja se nalazi sveukupno 3671 stan, no sva obilježja nisu dostupna za sve opservacije. U tablici 1 su prikazane sve korištene varijable, gdje je uz kratak opis naveden i njihov izvor te broj opservacija za koje je dostupno pojedino obilježje.

\section{Tablica 1:}

\section{OPIS VARIJABLI KORIŠTENIH U IZRADI HEDONIČKOG MODELA}

\begin{tabular}{|l|l|l|l|c|}
\hline Varijabla & \multicolumn{1}{|c|}{ Opis varijable } & \multicolumn{1}{|c|}{ Oznaka varijable } & Izvor & $\begin{array}{c}\text { Broj promatranja } \\
\text { za koje je obilježje } \\
\text { dostupno }\end{array}$ \\
\hline \multirow{2}{*}{$\begin{array}{l}\text { Cijena }(€) \\
\text { po m }\end{array}$} & $\begin{array}{l}\text { Tražena cijena kvadratnog metra } \\
\text { stambenog prostora }\end{array}$ & CIJENA1 & BN & 3671 \\
\cline { 2 - 5 } & $\begin{array}{l}\text { Postignuta cijena kvadratnog } \\
\text { metra stambenog prostora }\end{array}$ & CIJENA2 & BN & 2756 \\
\hline Površina & Površina u kvadratnim metrima & M2 & BN & 3671 \\
\hline $\begin{array}{l}\text { Prostorna } \\
\text { udaljenost od } \\
\text { centra grada }\end{array}$ & $\begin{array}{l}\text { Prostorna udaljenost mjerena u } \\
\text { kilometrima automobilom }\end{array}$ & AUTO_KM & MIREO & 3671 \\
\hline Broj soba & Broj soba u stanu & SOBE & BN & 3528 \\
\hline Kat & Kat zgrade na kojem se nalazi stan & KAT & BN & 3132 \\
\hline
\end{tabular}


T. SLIŠKOVIĆ, J. TICA: Značaj udaljenosti u hedonističkom modelu određivanja cijena stanova u Zagrebu EKONOMSKI PREGLED, 70 (5) 677-705 (2019)

Nastavak tablice 1.

\begin{tabular}{|c|c|c|c|c|}
\hline Varijabla & Opis varijable & Oznaka varijable & Izvor & $\begin{array}{c}\text { Broj promatranja } \\
\text { za koje je obilježje } \\
\text { dostupno }\end{array}$ \\
\hline Novogradnja & $\begin{array}{l}\text { Indikator varijabla. Stan je } \\
\text { klasificiran kao novogradnja } \\
\text { ukoliko je prodan u istoj godini } \\
\text { kada je izgrađen, ili najkasnije u } \\
\text { sljedećoj godini. }\end{array}$ & NOVOGRADNJA & $\begin{array}{l}\mathrm{BN}, \\
\text { autorica }\end{array}$ & 3267 \\
\hline Balkon & $\begin{array}{l}\text { Indikator varijabla kojom se } \\
\text { opisuje posjeduje li stan balkon }\end{array}$ & BALKON & $\mathrm{BN}$ & 3572 \\
\hline Lođa & $\begin{array}{l}\text { Indikator varijabla kojom se } \\
\text { opisuje posjeduje li stan lođu }\end{array}$ & LOGGIA & $\mathrm{BN}$ & 3534 \\
\hline Plin & $\begin{array}{l}\text { Indikator varijabla kojom se } \\
\text { opisuje posjeduje li stan plinski } \\
\text { priključak }\end{array}$ & PLIN & $\mathrm{BN}$ & 3313 \\
\hline Lift & $\begin{array}{l}\text { Indikator varijabla kojom se } \\
\text { opisuje posjeduje li zgrada lift }\end{array}$ & LIFT & $\mathrm{BN}$ & 3640 \\
\hline $\begin{array}{l}\text { Godina } \\
\text { prodaje }\end{array}$ & $\begin{array}{l}\text { Godina u kojoj je nekretnina } \\
\text { prodana na tržištu. Obuhvaćeno } \\
\text { je razdoblje 2002.-2013. godine, s } \\
\text { tim da je 2009. izostavljena } \\
\text { U analizu se uključuje kao } \\
\text { dummy varijabla s } 11 \text { modaliteta. }\end{array}$ & $\begin{array}{l}\text { 1. NUM2002 } \\
\text { 2. NUM } 2003 \\
\text { 7. NUM2008 } \\
\text { 8. NUM2010 } \\
\text { 11. NUM2013 } \\
\end{array}$ & $\mathrm{BN}$ & 3671 \\
\hline $\begin{array}{l}\text { Gradska } \\
\text { četvrt/zona }\end{array}$ & $\begin{array}{l}\text { Gradska četvrt/zona Grada } \\
\text { Zagreba u kojoj je stan lociran, } \\
\text { obuhvaća } 14 \text { modaliteta koji su } \\
\text { u analizu uključeni kao dummy } \\
\text { varijable. } \\
\text { NAPOMENA: } \\
\text { DCENTAR obuhvaća četvrti } \\
\text { Centar i Donji grad; } \\
\text { DGORNJI_MEDV obuhvaća } \\
\text { Gornji grad i Medveščak; } \\
\text { DTRESNJEVKA obuhvaća } \\
\text { četvrti Trešnjevka sjever i jug. }\end{array}$ & $\begin{array}{l}\text { 1. DCENTAR } \\
\text { 2. DCRNOMEREC } \\
\text { 3. DDUBRAVA } \\
\text { 4. DGORNJIMEDV } \\
\text { 5. DMAKSIMIR } \\
\text { 6. DNOVIZG } \\
\text { 7. DPESCENICA } \\
\text { 8. DPODSLJEME } \\
\text { 9. DPODSUSED } \\
\text { 10. DSESVETE } \\
\text { 11. DSTENJEVEC } \\
\text { 12. DTRNJE } \\
\text { 13. DTRESNJEVKA } \\
\text { 14. DOSTALO } \\
\end{array}$ & $\mathrm{BN}$ & 3671 \\
\hline Strana svijeta & $\begin{array}{l}\text { Strana svijeta na kojoj je } \\
\text { nekretnina locirana, obuhvaća } \\
8 \text { modaliteta koji su u analizu } \\
\text { uključeni kao dummy varijable: }\end{array}$ & $\begin{array}{l}1 . S \\
2 . \mathrm{I} \\
\text { 3. Z } \\
\text { 4. J } \\
\text { 5. SI } \\
\text { 6.SZ } \\
\text { 7. JI } \\
\text { 8. JZ }\end{array}$ & Autori & 3671 \\
\hline
\end{tabular}




\subsection{Metodologija}

\subsubsection{Konstruiranje najšireg hedoničkog modela}

Potpuni hedonički model u koji je implementiran faktor udaljenosti konstruira se na standardni način, u kojem je zavisna varijabla logaritam cijene kvadratnog metra stambenog prostora, a skup nezavisnih varijabli obuhvaća 46 nezavisnih varijabli iskazanih u razinama. Nezavisne varijable se ugrubo mogu svrstati u tri kategorije:

a) Lokacijske karakteristike: prostorna udaljenost te pripadnost pojedinim gradskim četvrtima i stranama svijeta ${ }^{4}$

b) Interne (kvalitativne) karakteristike nekretnina

c) Varijable koje modelu daju vremensku dimenziju: godina u kojoj je nekretnina prodana na tržištu.

Konkretan oblik modela koji se procjenjuje je naveden u jednadžbi 1:

$$
\begin{aligned}
& \operatorname{lnCIJENA}=\beta_{0}+\beta_{1} S+\beta_{2} I+\beta_{3} Z+\beta_{4} J+\beta_{5} S I+\beta_{6} J Z+\beta_{7} J I \\
& +\beta_{8} A U T O \_K M+\beta_{9} A U T O \_K M * S+\beta_{10} A U T O \_K M * I \\
& +\beta_{11} A U T O \_K M * Z+\beta_{12} A U T O \_K M * J+\beta_{13} A U T O \_K M * S I \\
& +\beta_{14} A U T O \_K M * J Z+\beta_{15} A U T O \_K M * J I++\beta_{16} D C R N O M E R E C \\
& +\beta_{17} D D U B R A V A+\beta_{18} D G O R N J I \_M E D V+\beta_{19} D M A K S I M I R \\
& +\beta_{20} \text { DNOVIZG }+\beta_{21} \text { DPESCENICA }+\beta_{22} \text { DPODSLJEME } \\
& +\beta_{23} \text { DPODSUSED }+\beta_{24} \text { DSESVETE }+\beta_{25} \text { DSTENJEVEC } \\
& +\beta_{26} \text { DTRESNJEVKA }+\beta_{27} \text { DTRNJE }+\beta_{28} \text { DOSTALO }+\beta_{29} M 2 \\
& +\beta_{30} S O B E+\beta_{31} \text { KAT }+\beta_{32} \text { NOVOGRADNJA }+\beta_{33} \text { BALKON } \\
& +\beta_{34} \text { LOGGIA }+\beta_{35} \text { PLIN }+\beta_{36} \text { LIFT }+\beta_{37} \text { NUM } 2003 \\
& +\beta_{38} N U M 2004+\beta_{39} N U M 2005+\beta_{40} N U M 2006+\beta_{41} N U M 2007 \\
& +\beta_{42} N U M 2008+\beta_{43} N U M 2010+\beta_{44} N U M 2011+\beta_{45} N U M 2012 \\
& +\beta_{46} N U M 2013+\varepsilon
\end{aligned}
$$

4 Matrica korelacije pokazala je kako ne postoji visoka korelacija između varijabli gradskih četvrti i strana svijeta (najviša vrijednost koeficijenta između dvije varijable iznosi 0,773 , što predstavlja rijetkost u odnosu na preostale koeficijente), pa je stoga procijenjeno kako je njihova istovremena uporaba u modelu opravdana. 
Varijabla CIJENA obuhvaća dva modaliteta-tražene (Cijena1) i postignute (Cijena2). Stoga će se i model procjenjivati u dvije varijante.

Kako bi se, zbog velikog broja indikator varijabli, izbjegao potencijalni problem savršene koreliranosti regresora (zamke dummy varijabli), iz jednadžbe je izostavljen po jedan modalitet lokacijskih i vremenskih dummy varijabli. $\mathrm{U}$ tom slučaju, izostavljeni modalitet predstavlja baznu, odnosno referentnu grupu, koja se interpretira kroz konstantni član regresije ${ }^{5}\left(\beta_{0}\right)$.

Model prezentiran jednadžbom 1 je postavljen na način da konstantni član regresije predstavlja stanove koji su locirani u gradskoj četvrti Centar ${ }^{6}$, pripadaju strani svijeta Sjeverozapad te su na tržištu prodani tijekom 2002. godine. Motivacija za ovakav odabir baznih modaliteta je sljedeća:

- Zona Centar predstavlja bazni modalitet zbog pretpostavke da će prosječne cijene u svim preostalim gradskim zonama biti signifikantno različite i u većini slučajeva manje od onih u zoni Centar.

- U svrhu jednostavnosti interpretacije vremenske dimenzije, za bazni modalitet je postavljena 2002. godina.

- Posebno obrazloženje potrebno je za odabir strane svijeta Sjeverozapad kao baznog modaliteta. Naime, prethodna istraživanja (Boras (2012) i Slišković i Tica (2016)) su ukazala na specifičnost Sjeverozapada. Konkretno, pokazalo se kako su nagibi funkcija cijena stambenog prostora negativni na svim stranama svijeta, osim na sjeverozapadu.

Polazni hedonički model je široko postavljen kako bi se ispitalo je li model koji u sebi sadrži varijable strana svijeta (varijable uz parametre $\beta_{1}$ do $\beta_{7}$ i posebice varijable kojima se iskazuje efekt udaljenosti od središta grada (varijable uz parametre $\beta_{8}$ do $\beta_{15}$, potpuniji u odnosu na one koji su se do sada koristili za modeliranje cijena stambenog prostora u Gradu Zagrebu.

5 U takvom slučaju, interpretacija regresijskih parametara je takva da konstantni član regresije predstavlja bazni modalitet, dok parametri uz ostale modalitete dummy varijable predstavljaju razlike tih modaliteta u odnosu na bazni. Ukoliko procjena modela pokaže da je procijenjeni koeficijent uz određeni modalitet dummy varijable signifikantan, to ne znači da je taj modalitet značajan u modelu pri određenoj razini signifikantnosti, već da je za iznos koeficijenta značajno različit od koeficijenta baznog modaliteta (Wooldridge, 2013).

6 Obuhvaća područja gradskih četvrti Centar i Donji grad 


\subsubsection{Waldov test}

Testiranje hipoteze da je ovdje predstavljeni model potpuniji u odnosu na dosadašnje će se provoditi u nekoliko koraka. Prvenstveno će se, pristupom „od općeg ka specifičnom“, iz najšireg modela postupno formirati njegovi uži oblici iz kojeg će se isključivati pojedine srodne skupine varijabli. Temeljna ideja istraživanja je ispitivanje jesu li grupe varijabli koje su uvrštene u polaznom hedoničkom modelu (jednadžba 1), a koje do sada nisu korištene u praksi hedoničkog modeliranja na zagrebačkom stambenom tržištu skupno značajne za objašnjavanje varijacija u cijenama stambenog prostora. Tehnički će se na pojedine skupine parametara postaviti ograničenje jednakosti s nulom. Testiranje ograničenja na parametre se provodi primjenom pojedinačnog ili skupnog Waldovog testa:

$$
W=(R b-r)^{\prime}\left(R s^{2}\left(X^{\prime} X\right)^{-1} R^{\prime}\right)^{-1}(R b-r)
$$

Odbacivanje postavljene nulte hipoteze u kojoj su postavljena ograničenja na parametre u smislu da su parametri uz pojedine grupe varijabli izjednačene s nulom vodi do zaključka kako prisutnost tih varijabli u modelu doprinosi boljoj prilagođenosti modela podacima. Dobiveni rezultati se mogu interpretirati i na način da daju odgovor na pitanje je li povećanje koeficijenta determinacije (koje je neminovno zbog uvođenja više regresora u model) doista statistički značajno.

\section{REZULTATI}

U prvoj fazi testiranja hipoteze da je model postavljen u ovom radu potpuniji u odnosu na hedoničke modele korištene u dosadašnjoj praksi procijenjeni su modeli u kojima je zavisna varijabla tražena cijena stambenog prostora. Veći broj opservacija o traženim cijenama u odnosu na postignute je razlog za prioritetnu procjenu hedoničkog modela s tom varijantom cijena ${ }^{7}$. Prva faza ispitivanja odnosi se na procjenu 5 formiranih modela. Pri tome je polazni model, prezentiran u jed-

7 Činjenica je da tražene cijene nisu najrealniji pokazatelj stanja na tržištu zbog čestih nerealnih zahtjeva prodavatelja, kao i to da se vrlo često razlikuju od onih koje su u procesu kupoprodaje postignute. No, već je istraživanje Kunovca i sur. (2008) pokazalo kako i baze koje sadrže tražene cijene mogu biti dobar temelj za izradu istraživanja, obzirom da se rezultati dobiveni na temelju njih ne razlikuju značajno od onih dobivenih na temelju postignutih cijena. Do identičnog zaključka dovodi i ovo istraživanje. 
nadžbi 1 označen nazivom ,Model 1“. Potom su formirana 4 njegova uža oblika na način da su iz početnog modela isključivane cijele grupe varijabli na koje se postavlja ograničenje jednakosti s nulom, a što se testira pomoću Waldovog testa. U najužem, modelu 5, je lokacija opisana jedino varijablama koje označavaju gradske četvrti/zone u kojima su stambene nekretnine smještene, pa se može reći da je on najsličniji modelima koji su korišteni u dosadašnjoj praksi. Tablica 2 prikazuje konkretne grupe koeficijenata koje će se izjednačavati s nulom u pojedinim užim oblicima modela.

\section{Tablica 2:}

\section{UŽI OBLICI POLAZNOG HEDONIČKOG MODELA}

\begin{tabular}{|l|l|}
\hline Model 2 & $\beta_{1}=\beta_{2}=\beta_{3}=\beta_{4}=\beta_{5}=\beta_{6}=\beta_{7}=0$ \\
\hline Model 3 & $\beta_{9}=\beta_{10}=\beta_{11}=\beta_{12}=\beta_{13}=\beta_{14}=\beta_{15}=0$ \\
\hline Model 4 & $\beta_{1}=\beta_{2}=\beta_{3}=\beta_{4}=\beta_{5}=\beta_{6}=\beta_{7}=\beta_{9}=\beta_{10}=\beta_{11}=\beta_{12}=\beta_{13}=\beta_{14}=\beta_{15}=0$ \\
\hline Model 5 & $\beta_{1}=\beta_{2}=\beta_{3}=\beta_{4}=\beta_{5}=\beta_{6}=\beta_{7}=\beta_{8}=\beta_{9}=\beta_{10}=\beta_{11}=\beta_{12}=\beta_{13}=\beta_{14}=\beta_{15}=0$ \\
\hline
\end{tabular}

U svim definiranim modelima su parametri procijenjeni metodom najmanjih kvadrata. U svrhu otklanjanja problema heteroskedastičnosti, u svim modelima je provedena Whiteova korekcija standardnih pogrešaka procjene parametara. Rezultati procjene su, skupa s vrijednostima koeficijenata determinacije prezentirani u tablici 3. 
Tablica 3:

REZULTATI PROCJENE HEDONIČKIH MODELA TRAŽENIH CIJENA

\begin{tabular}{|c|c|c|c|c|c|c|c|}
\hline & Model: & Model 1 & Model 2 & Model 3 & Model 4 & Model 5 & Model 6 \\
\hline & Dep.Var: & \multicolumn{6}{|c|}{ LCIJENA1 } \\
\hline$\beta_{0}$ & $\mathrm{C}$ & $\begin{array}{c}6.687 \\
{[74.126]^{* *}}\end{array}$ & $\begin{array}{c}7.221 \\
{[282.241]^{* *}}\end{array}$ & $\begin{array}{c}7.229 \\
{[201.551]^{* *}}\end{array}$ & $\begin{array}{c}7.196 \\
{[288.365]^{* *}}\end{array}$ & $\begin{array}{c}7.152 \\
{[290.648]^{* *}}\end{array}$ & $\begin{array}{c}6.748 \\
{[75.901]^{* *}}\end{array}$ \\
\hline \multirow{5}{*}{$\begin{array}{l}\beta_{1} \\
\beta_{2} \\
\beta_{3} \\
\beta_{4}\end{array}$} & S & $\begin{array}{c}0.622 \\
{[6.821]^{* *}}\end{array}$ & & $\begin{array}{c}0.077 \\
{[2.846]^{* *}}\end{array}$ & & & \\
\hline & I & $\begin{array}{c}0.437 \\
{[4.861]^{* *}}\end{array}$ & & $\begin{array}{c}-0.070 \\
{[-2.243]^{*}}\end{array}$ & & & \\
\hline & Z & 0.476 & & -0.005 & & & \\
\hline & $\mathrm{J}$ & {$[4.948]^{* *}$} & & {$[-0.213]$} & & & \\
\hline & & $\begin{array}{c}0.579 \\
{[5.989]^{* *}}\end{array}$ & & $\begin{array}{c}-0.029 \\
{[-0.953]}\end{array}$ & & & \\
\hline \multirow{2}{*}{$\beta_{5}$} & SI & 0.469 & & -0.165 & & & \\
\hline & & {$[1.912]$} & & {$[-2.953]^{* *}$} & & & \\
\hline \multirow[t]{2}{*}{$\beta_{6}$} & $\mathrm{JZ}$ & $\begin{array}{c}0.658 \\
\end{array}$ & & 0.065 & & & \\
\hline & & $\begin{array}{c}{[6.895]^{* *}} \\
0.536\end{array}$ & & $\begin{array}{c}{[2.245]^{*}} \\
-0.052\end{array}$ & & & \\
\hline$\beta_{7}$ & & {$[5.726]^{* *}$} & & {$[-1.714]$} & & & \\
\hline$\beta_{8}$ & AUTO_KM & $\begin{array}{c}0.044 \\
{[4.806]^{* *}}\end{array}$ & $\begin{array}{c}-0.013 \\
{[-3.771]^{* *}}\end{array}$ & $\begin{array}{c}-0.017 \\
{[-7.452]^{* *}}\end{array}$ & $\begin{array}{c}-0.018 \\
{[-8.288]^{* *}}\end{array}$ & & $\begin{array}{c}0.038 \\
{[4.264]^{* *}}\end{array}$ \\
\hline \multirow{2}{*}{$\begin{array}{l}\beta_{9} \\
\beta_{10}\end{array}$} & AUTO_KM*S & $\begin{array}{c}-0.063 \\
{[-6.003]^{* *}}\end{array}$ & $\begin{array}{c}0.011 \\
{[3.190]^{* *}}\end{array}$ & & & & \\
\hline & AUTO_KM*I & -0.051 & -0.013 & & & & \\
\hline \multirow{2}{*}{$\beta_{11}$} & AUTO_KM*Z & $\begin{array}{c}{[-5.188]^{* *}} \\
-0.053\end{array}$ & $\begin{array}{c}{[-2.696]^{* *}} \\
-0.003\end{array}$ & & & & \\
\hline & & {$[-5.533]^{* *}$} & {$[-1.394]$} & & & & \\
\hline \multirow{2}{*}{$\beta_{12}$} & AUTO_KM*J & -0.076 & -0.014 & & & & \\
\hline & & {$[-7.023]^{* *}$} & {$[-3.927]^{* *}$} & & & & \\
\hline \multirow[t]{2}{*}{$\beta_{13}$} & AUTO_KM*SI & -0.071 & -0.024 & & & & \\
\hline & & {$[-2.773] * *$} & {$[-3.839]^{* *}$} & & & & \\
\hline \multirow{2}{*}{$\beta_{14}$} & AUTO_KM*JZ & -0.070 & -0.001 & & & & \\
\hline & & {$[-7.239] * *$} & {$[-0.269]$} & & & & \\
\hline$\beta_{15}$ & AUTO_KM*JI & $\begin{array}{c}-0.072 \\
{[-6.829]^{* *}}\end{array}$ & $\begin{array}{c}-0.017 \\
{[-4.326]^{* *}}\end{array}$ & & & & \\
\hline$\beta_{16}$ & DCRNOMEREC & $\begin{array}{c}-0.063 \\
{[-2.313]^{*}}\end{array}$ & $\begin{array}{c}-0.088 \\
{[-3.507]^{* *}}\end{array}$ & $\begin{array}{c}-0.086 \\
{[-3.380]^{* *}}\end{array}$ & $\begin{array}{c}-0.010 \\
{[-0.492]}\end{array}$ & $\begin{array}{c}-0.079 \\
{[-4.573] * *}\end{array}$ & $\begin{array}{c}-0.085 \\
{[-3.302]^{* *}}\end{array}$ \\
\hline \multirow{2}{*}{$\beta_{17}$} & DDUBRAVA & -0.258 & -0.218 & -0.232 & -0.272 & -0.356 & -0.247 \\
\hline & & {$[-7.640]^{* *}$} & {$[-5.795]^{* *}$} & {$[-7.418]^{* *}$} & {$[-10.606]^{* *}$} & {$[-14.944]^{* *}$} & {$[-7.897]^{* *}$} \\
\hline \multirow[t]{2}{*}{$\beta_{18}$} & DGORNJI_MEDV & 0.032 & 0.053 & 0.022 & 0.097 & 0.097 & 0.014 \\
\hline & & [1.143] & {$[2.300]^{*}$} & {$[0.881]$} & {$[4.318]^{* *}$} & {$[4.247]^{* *}$} & {$[0.568]$} \\
\hline \multirow{2}{*}{$\beta_{19}$} & DMAKSIMIR & -0.042 & -0.040 & -0.050 & 0.000 & -0.021 & -0.063 \\
\hline & & {$[-1.644]$} & {$[-1.831]$} & {$[-2.043]^{*}$} & {$[0.021]$} & {$[-1.105]$} & {$[-2.773]^{* *}$} \\
\hline \multirow{2}{*}{$\beta_{20}$} & DNOVIZG & -0.157 & -0.143 & -0.202 & -0.166 & -0.246 & -0.171 \\
\hline & & {$[-5.971]^{* *}$} & {$[-6.516]^{* *}$} & {$[-9.792]^{* *}$} & {$[-8.558]^{* *}$} & {$[-15.219]^{* *}$} & {$[-8.890]^{* *}$} \\
\hline
\end{tabular}


T. SLIŠKOVIĆ, J. TICA: Značaj udaljenosti u hedonističkom modelu određivanja cijena stanova u Zagrebu EKONOMSKI PREGLED, 70 (5) 677-705 (2019)

Nastavak tablice 3.

\begin{tabular}{|c|c|c|c|c|c|c|c|}
\hline & Model: & Model 1 & Model 2 & Model 3 & Model 4 & Model 5 & Model 6 \\
\hline & Dep. Var: & \multicolumn{6}{|c|}{ LCIJENA1 } \\
\hline$\beta_{21}$ & DPESCENICA & $\begin{array}{c}-0.133 \\
{[-6.618]^{* *}}\end{array}$ & $\begin{array}{c}-0.125 \\
{[-6.356]^{* *}}\end{array}$ & $\begin{array}{c}-0.151 \\
{[-8.379]^{* *}}\end{array}$ & $\begin{array}{c}-0.168 \\
{[-9.672]^{* *}}\end{array}$ & $\begin{array}{c}-0.203 \\
{[-11.938]^{* *}}\end{array}$ & $\begin{array}{c}-0.156 \\
{[-9.044]^{* *}}\end{array}$ \\
\hline \multirow{2}{*}{$\beta_{22}$} & DPODSLJEME & -0.100 & -0.109 & -0.114 & -0.014 & -0.056 & -0.132 \\
\hline & & {$[-3.300]^{* *}$} & {$[-3.960]^{* *}$} & {$[-3.877]^{* *}$} & {$[-0.630]$} & {$[-2.561]^{*}$} & {$[-4.730]^{* *}$} \\
\hline \multirow{2}{*}{$\beta_{23}$} & DPODSUSED & -0.214 & -0.179 & -0.174 & -0.135 & -0.272 & -0.206 \\
\hline & & {$[-6.775]^{* *}$} & {$[-6.015]^{* *}$} & {$[-5.997]^{* *}$} & {$[-5.188]^{* *}$} & {$[-14.503]^{* *}$} & {$[-7.136]^{* *}$} \\
\hline \multirow{2}{*}{$\beta_{24}$} & DSESVETE & -0.391 & -0.276 & -0.325 & -0.357 & -0.503 & -0.336 \\
\hline & & {$[-8.411]^{* *}$} & {$[-3.576]^{* *}$} & {$[-6.575]^{* *}$} & {$[-7.700]^{* *}$} & {$[-14.751]^{* *}$} & {$[-7.025]^{* *}$} \\
\hline \multirow{2}{*}{$\beta_{25}$} & DSTENJEVEC & -0.229 & -0.215 & -0.240 & -0.169 & -0.291 & -0.225 \\
\hline & & {$[-8.645]^{* *}$} & {$[-9.074] * *$} & {$[-9.897]^{* *}$} & {$[-7.418]^{* *}$} & {$[-17.179]^{* *}$} & {$[-9.725]^{* *}$} \\
\hline \multirow{2}{*}{$\beta_{26}$} & DTRESNJEVKA & -0.189 & -0.152 & -0.203 & -0.108 & -0.167 & -0.183 \\
\hline & & {$[-7.413]^{* *}$} & {$[-8.147]^{* *}$} & {$[-9.776]^{* *}$} & {$[-6.296]^{* *}$} & {$[-11.053]^{* *}$} & {$[-9.765]^{* *}$} \\
\hline \multirow{2}{*}{$\beta_{27}$} & DTRNJE & -0.100 & -0.080 & -0.109 & -0.109 & -0.136 & -0.098 \\
\hline & & {$[-4.665]^{* *}$} & {$[-3.832]^{* *}$} & {$[-5.124]^{* *}$} & {$[-5.623]^{* *}$} & {$[-7.085]^{* *}$} & {$[-5.014]^{* *}$} \\
\hline \multirow{2}{*}{$\beta_{28}$} & DOSTALO & 0.032 & 0.054 & -0.003 & 0.027 & -0.056 & 0.008 \\
\hline & & {$[0.367]$} & {$[0.644]$} & {$[-0.040]$} & {$[0.277]$} & {$[-0.527]$} & [0.097] \\
\hline$\beta_{29}$ & M2 & $\begin{array}{c}0.001 \\
{[3.505]^{* *}}\end{array}$ & $\begin{array}{c}0.001 \\
{[3.572]^{* *}}\end{array}$ & $\begin{array}{c}0.001 \\
{[3.507]^{* *}}\end{array}$ & $\begin{array}{c}0.001 \\
{[4.505]^{* *}}\end{array}$ & $\begin{array}{c}0.001 \\
{[4.834]^{* *}}\end{array}$ & $\begin{array}{c}0.001 \\
{[3.459]^{* *}}\end{array}$ \\
\hline \multirow{2}{*}{$\beta_{30}$} & SOBE & -0.009 & -0.008 & -0.008 & -0.010 & -0.014 & -0.009 \\
\hline & & {$[-1.746]$} & {$[-1.447]$} & {$[-1.521]$} & {$[-1.898]$} & {$[-2.501]^{*}$} & {$[-1.743]$} \\
\hline \multirow{2}{*}{$\beta_{31}$} & KAT & -0.004 & -0.004 & -0.004 & -0.004 & -0.004 & -0.004 \\
\hline & & {$[-2.301]^{*}$} & {$[-2.493]^{*}$} & {$[-2.195]^{*}$} & {$[-2.441]^{*}$} & {$[-2.182]^{*}$} & {$[-2.126]^{*}$} \\
\hline \multirow{2}{*}{$\beta_{32}$} & NOVOGRADNJA & 0.063 & 0.062 & 0.063 & 0.059 & 0.055 & 0.061 \\
\hline & & {$[7.714]^{* *}$} & {$[7.582]^{* *}$} & {$[7.567]^{* *}$} & {$[7.069]^{* *}$} & {$[6.312]^{* *}$} & {$[7.402]^{* *}$} \\
\hline \multirow{2}{*}{$\beta_{33}$} & BALKON & 0.000 & -0.002 & -0.002 & -0.001 & -0.003 & -0.001 \\
\hline & & {$[0.033]$} & {$[-0.276]$} & {$[-0.223]$} & {$[-0.145]$} & {$[-0.322]$} & {$[-0.165]$} \\
\hline \multirow{2}{*}{$\beta_{34}$} & LOGGIA & 0.013 & 0.010 & 0.011 & 0.006 & 0.004 & 0.013 \\
\hline & & [1.594] & {$[1.217]$} & {$[1.402]$} & {$[0.667]$} & {$[0.434]$} & {$[1.580]$} \\
\hline \multirow{2}{*}{$\beta_{35}$} & PLIN & 0.025 & 0.027 & 0.028 & 0.024 & 0.029 & 0.025 \\
\hline & & {$[2.571]^{*}$} & {$[2.688]^{* *}$} & {$[2.842]^{* *}$} & {$[2.367]^{*}$} & {$[2.845]^{* *}$} & {$[2.530]^{*}$} \\
\hline \multirow{2}{*}{$\beta_{36}$} & LIFT & 0.079 & 0.082 & 0.081 & 0.078 & 0.080 & 0.084 \\
\hline & & {$[8.343]^{* *}$} & {$[8.796]^{* *}$} & {$[8.649]^{* *}$} & {$[8.568]^{* *}$} & {$[8.544]^{* *}$} & {$[9.465]^{* *}$} \\
\hline \multirow{2}{*}{$\beta_{37}$} & NUM2003 & 0.097 & 0.100 & 0.099 & 0.115 & 0.114 & 0.093 \\
\hline & & {$[2.546]^{*}$} & {$[2.741]^{* *}$} & {$[2.630]^{* *}$} & {$[2.920]^{* *}$} & {$[2.943]^{* *}$} & {$[2.513]^{*}$} \\
\hline \multirow{2}{*}{$\beta_{38}$} & NUM2004 & 0.130 & 0.092 & 0.107 & 0.136 & 0.103 & 0.111 \\
\hline & & {$[2.930]^{* *}$} & [1.912] & {$[2.444]^{*}$} & {$[3.541]^{* *}$} & {$[2.239]^{*}$} & {$[2.417]^{*}$} \\
\hline \multirow[t]{2}{*}{$\beta_{39}$} & NUM2005 & 0.260 & 0.254 & 0.262 & 0.256 & 0.248 & 0.263 \\
\hline & & {$[5.546]^{* *}$} & {$[5.215]^{* *}$} & {$[5.597]^{* *}$} & {$[4.628]^{* *}$} & {$[4.150]^{* *}$} & {$[5.197]^{* *}$} \\
\hline \multirow{2}{*}{$\beta_{40}$} & NUM2006 & 0.471 & 0.466 & 0.466 & 0.473 & 0.465 & 0.473 \\
\hline & & {$[26.611]^{* *}$} & {$[26.256]^{* *}$} & {$[26.563]^{* *}$} & {$[26.792]^{* *}$} & {$[25.950]^{* *}$} & {$[27.147]^{* *}$} \\
\hline \multirow{2}{*}{$\beta_{41}$} & NUM2007 & 0.625 & 0.616 & 0.619 & 0.612 & 0.600 & 0.623 \\
\hline & & {$[35.776]^{* *}$} & {$[35.652]^{* *}$} & {$[36.551]^{* *}$} & {$[35.484]^{* *}$} & {$[34.233]^{* *}$} & {$[36.622]^{* *}$} \\
\hline \multirow{2}{*}{$\beta_{42}$} & NUM2008 & 0.514 & 0.511 & 0.509 & 0.518 & 0.519 & 0.512 \\
\hline & & {$[14.708]^{* *}$} & {$[14.272]^{* *}$} & {$[14.830]^{* *}$} & {$[14.445]^{* *}$} & {$[14.337]^{* *}$} & {$[14.856]^{* *}$} \\
\hline
\end{tabular}


Nastavak tablice 3.

\begin{tabular}{|c|c|c|c|c|c|c|c|}
\hline & Model: & Model 1 & Model 2 & Model 3 & Model 4 & Model 5 & Model 6 \\
\hline & Dep.Var: & \multicolumn{6}{|c|}{ LCIJENA1 } \\
\hline$\beta_{43}$ & NUM2010 & $\begin{array}{c}0.487 \\
{[37.923]^{* *}}\end{array}$ & $\begin{array}{c}0.482 \\
{[37.250] * *}\end{array}$ & $\begin{array}{c}0.484 \\
{[37.667]^{* *}}\end{array}$ & $\begin{array}{c}0.485 \\
{[36.864]^{* *}}\end{array}$ & $\begin{array}{c}0.473 \\
{[35.247]^{* *}}\end{array}$ & $\begin{array}{c}0.484 \\
{[37.820]^{* *}}\end{array}$ \\
\hline \multirow{2}{*}{$\beta_{44}$} & NUM2011 & 0.420 & 0.417 & 0.419 & 0.431 & 0.418 & 0.420 \\
\hline & & {$[30.577]^{* *}$} & {$[29.828]^{* *}$} & {$[30.654]^{* *}$} & {$[30.720]^{* *}$} & {$[28.859]^{* *}$} & {$[31.408]^{* *}$} \\
\hline \multirow{2}{*}{$\beta_{45}$} & NUM2012 & 0.373 & 0.366 & 0.369 & 0.377 & 0.371 & 0.371 \\
\hline & & {$[19.523]^{* *}$} & {$[18.955]^{* *}$} & {$[19.326]^{* *}$} & {$[19.322]^{* *}$} & {$[18.550]^{* *}$} & {$[19.389]^{* *}$} \\
\hline \multirow{2}{*}{$\beta_{46}$} & NUM2013 & 0.284 & 0.283 & 0.283 & 0.285 & 0.281 & 0.283 \\
\hline & & {$[17.099]^{* *}$} & {$[16.961]^{* *}$} & {$[17.057]^{* *}$} & {$[16.916]^{* *}$} & {$[16.347]^{* *}$} & {$[17.118]^{* *}$} \\
\hline & & & & & & & $\begin{array}{c}0.467 \\
{[5.287]^{* *}}\end{array}$ \\
\hline & S_JZ & & & & & & 0.567 \\
\hline & $I_{\mathrm{C}}$ & & & & & & {$[6.608]^{* *}$} \\
\hline & I_SI & & & & & & $\begin{array}{c}0.406 \\
{[4.556]^{* *}}\end{array}$ \\
\hline & AUTO_KM*JZ_J_ & & & & & & -0.061 \\
\hline & AUTO_KM*S_ & & & & & & $\begin{array}{c}{[-6.853]^{* *}} \\
-0.053 \\
{[-5.902]^{*} *}\end{array}$ \\
\hline & DI_-_L & & & & & & {$[-3.902]^{\infty}$} \\
\hline & Observations: & 2798 & 2798 & 2798 & 2798 & 2798 & 2798 \\
\hline & R-squared: & 0.587 & 0.574 & 0.578 & 0.557 & 0.545 & 0.583 \\
\hline & F-statistic: & 84.920 & 95.181 & 96.908 & 108.558 & 106.715 & 104.379 \\
\hline
\end{tabular}

Napomena: U zagradama su navedene vrijednosti t-statistike. Zvjezdice uz t-statistiku upućuju na odbacivanje nulte hipoteze o neznačajnosti varijable u modelu na razini signifikantnosti od $1 \%(* *)$ i $5 \%(*)$.

Rezultati procjene najšireg postavljenog modela (Model 1) su gotovo u potpunosti u skladu s početnim očekivanja i ekonomskom intuicijom. Procjena je potvrdila polaznu pretpostavku autora da je strana svijeta Sjeverozapad specifična u odnosu na preostale strane svijeta. Iz procijenjenih parametara $\beta_{1}$ do $\beta_{7}$ modela 1 je razvidno kako je odsječak na osi za prosječne cijene stambenih nekretnina na svim ostalim stranama svijeta statistički različit od sjeverozapada, i to na razini statističke značajnosti od $1 \%$. Izuzetak je Sjeveroistok, za koji vrijedi da je značajno različit od baznog modaliteta na razini signifikantnosti od $10 \%$.

Najznačajniji rezultati procjene ovog modela su zapravo oni kojima se opisuju efekti udaljavanja od centra grada. Potvrđen je pozitivan nagib funkcije stambenog prostora na strani svijeta Sjeverozapad. Pozitivan predznak parametra $\beta_{8}$ ukazuje na povećanje traženih cijena kvadratnog metra za $4 \%$ sa svakim dodatnim kilometrom udaljavanja od središta grada u smjeru sjeverozapada, ukoliko su svi ostali faktori konstantni (do ruba promatranog područja).

Specifičnost Sjeverozapada je još jednom potvrđena procjenom parametara $\beta_{9}$ do $\beta_{15}$, koji pokazuju kako su efekti udaljavanja od središta grada u preostalih 7 
smjerova signifikantno različiti od referentne kategorije na razini signifikantnosti od $1 \%$. Procijenjeni parametri su očekivano negativni, i pokazuju kako tražene cijene opadaju sa svakim dodatnim kilometrom udaljavanja od gradskog središta. Pri tome najbrže opadaju ukoliko se radi o udaljavanju prema jugu grada. Konkretno, svaki dodatni kilometar udaljenosti u smjeru juga u prosjeku smanjuje cijenu za 3,2\% (0,044 za bazni modalitet plus -0,076 za jug).

Rezultati procjene parametara uz varijable kojima se opisuje smještaj stana u pojedinim gradskim zonama/četvrtima su gotovo u potpunosti u skladu s očekivanjima. Može se zaključiti kako su prosječne tražene cijene u gotovo svim promatranim zonama niže u odnosu na zonu Centar. Konstantni članovi u zonama Gornjeg grada i Medveščaka, Maksimira te u skupini „ostalo“ nisu značajno različiti od konstantnog člana cjelokupne regresije.

Vrlo očekivan i logičan rezultat vezan je uz varijable koje modelu daju vremensku dimenziju. Pokazano je kako su sve varijable kojima se opisuje godina prodaje značajno različite od bazne, 2002. godine. Tražene cijene su u prosjeku bile više u svim godinama u odnosu na baznu. Rastući trend je prisutan do 2007. godine, nakon čega slijedi smanjenje razlika u odnosu na 2002. godinu. Takva kretanja su potpuno u skladu s nastupanjem krize u gospodarstvu, građevinarstvu i na tržištu nekretnina u cijelosti.

Interpretacija učinaka internih karakteristika na tražene cijene nekretnina pokazuje kako su, sasvim očekivano, tražene cijene stanova u prosjeku više ukoliko je stan novogradnja, posjeduje plinski priključak, te ukoliko stambeni objekt posjeduje lift. Prosječne tražene cijene su također više ukoliko se stan nalazi na višim katovima, no iznos procijenjenog koeficijenta je zanemarivo malo. Pomalo iznenađujući rezultat je onaj koji pokazuje kako pozitivan učinak na tražene cijene ima površina stana, no iznos procijenjenog parametra je zanemarivo mali i iznosi 0,000578 . Iako se površina stana i broj soba na prvi pogled mogu smatrati varijablama koje prikazuju sličnu karakteristiku, pokazano je kako procijenjeni parametar uz varijablu broj soba, suprotno od varijable površina, ima negativan predznak, no statistički je različit od nule tek na razini signifikantnosti od $10 \%{ }^{8}$. Negativan predznak uz varijablu „,broj soba“ bi mogao oslikavati uvriježeno mišljenje da veći stanovi imaju nešto niže cijene kvadratnog metra. Važno je istaknuti da je ovo već drugo istraživanje i to rađeno na sasvim različitoj bazi podataka koje ukazuje kako površina stana ne djeluje statistički snažno na cijenu stana po kvadratu.

Pri interpretaciji procjena preostalih modela nema većih razlika u smislu statističke značajnosti i dobivenih predznaka. Model 5, koji je najsličniji do sada korištenim hedoničkim modelima, rezultira procjenama koje su u potpunosti u skladu

8 Ako se u modelu koristi samo varijabla površina (bez broja soba) zaključak ostaje nepromijenjen (pozitivan, ali zanemarivo mal procijenjeni parametar). 
s očekivanjima. Stoga je sljedeći korak analize bio usporedba najšireg hedoničkog modela (modela 1) s njegovim užim oblicima, uključujući i onaj kojim se može aproksimirati postojeća praksa hedoničkog modeliranja. Rezultati provedenog Waldovog testa su prikazani u Tablici 4 i pokazuju kako se, u svim slučajevima, može odbaciti nulta hipoteza kako su pojedine skupine varijabli skupno neznačajne za objašnjavanje varijacija u traženim cijenama. Obzirom da najširi model zbog najvećeg broja regresora ima i veći koeficijent determinacije, na temelju rezultata provedene analize se može zaključiti kako je porast tog koeficijenta uslijed uvođenja novih lokacijskih varijabli u hedonički model statistički značajan.

\section{Tablica 4:}

\section{REZULTATI PROVEDENOG WALDOVOG TESTA ZA SKUPINE VARIJABLI U MODELU TRAŽENIH CIJENA}

\begin{tabular}{|l|c|}
\hline & $\begin{array}{c}\text { Wald test } \\
\text { p-value }\end{array}$ \\
\hline$\beta_{1}=\beta_{2}=\beta_{3}=\beta_{4}=\beta_{5}=\beta_{6}=\beta_{7}=0$ & 0.00000 \\
\hline$\beta_{9}=\beta_{10}=\beta_{11}=\beta_{12}=\beta_{13}=\beta_{14}=\beta_{15}=0$ & 0.00000 \\
\hline$\beta_{1}=\beta_{2}=\beta_{3}=\beta_{4}=\beta_{5}=\beta_{6}=\beta_{7}=\beta_{9}=\beta_{10}=\beta_{11}=\beta_{12}=\beta_{13}=\beta_{14}=\beta_{15}=0$ & 0.00000 \\
\hline$\beta_{1}=\beta_{2}=\beta_{3}=\beta_{4}=\beta_{5}=\beta_{6}=\beta_{7}=\beta_{8}=\beta_{9}=\beta_{10}=\beta_{11}=\beta_{12}=\beta_{13}=\beta_{14}=\beta_{15}=0$ & 0.00000 \\
\hline
\end{tabular}

Provjera robusnosti dobivenih zaključaka izvršena je formiranjem i procjenom 5 ranije definiranih modela, ali s postignutim cijenama kvadratnog metra stambenog prostora kao zavisnom varijablom. Procjene hedoničkih modela postignutih cijena su izvršene na temelju nešto manjeg broja promatranja u odnosu na varijante traženih cijena, jer je za manji broj stanova postojao podatak o cijeni koja je postignuta pri kupoprodaji. Rezultati procjena polaznog i suženih hedoničkih modela postignutih cijena su prezentirani u Tablici 5. 
T. SLIŠKOVIĆ, J. TICA: Značaj udaljenosti u hedonističkom modelu određivanja cijena stanova u Zagrebu

Tablica 5:

REZULTATI PROCJENE HEDONIČKIH MODELA POSTIGNUTIH CIJENA

\begin{tabular}{|c|c|c|c|c|c|c|}
\hline & Model: & Model 1 & Model 2 & Model 3 & Model 4 & Model 5 \\
\hline & Dep. Var: & \multicolumn{5}{|c|}{ LCIJENA2 } \\
\hline$\beta_{0}$ & $\mathrm{C}$ & $\begin{array}{c}6.673 \\
{[66.425]^{* *}}\end{array}$ & $\begin{array}{c}7.180 \\
{[238.478]^{* *}} \\
\end{array}$ & $\begin{array}{c}7.159 \\
{[179.695]^{* *}}\end{array}$ & $\begin{array}{c}7.170 \\
{[243.488]^{* *}}\end{array}$ & $\begin{array}{c}7.132 \\
{[246.373]^{* *}}\end{array}$ \\
\hline$\beta_{1}$ & $S$ & $\begin{array}{c}0.629 \\
{[6.283]^{* *}}\end{array}$ & & $\begin{array}{c}0.100 \\
{[3.812]^{* *}}\end{array}$ & & \\
\hline$\beta_{2}$ & I & $\begin{array}{c}0.441 \\
{[4.453]^{* *}}\end{array}$ & & $\begin{array}{c}-0.021 \\
{[-0.656]}\end{array}$ & & \\
\hline \multirow{2}{*}{$\beta_{3}$} & Z & 0.454 & & 0.009 & & \\
\hline & & {$[4.281]^{* *}$} & & {$[0.348]$} & & \\
\hline \multirow{2}{*}{$\beta_{4}$} & $\mathrm{~J}$ & 0.510 & & 0.021 & & \\
\hline & & {$[4.836]^{* *}$} & & {$[0.657]$} & & \\
\hline \multirow{2}{*}{$\beta_{5}$} & SI & 0.503 & & -0.127 & & \\
\hline & & {$[1.667]$} & & {$[-1.775]$} & & \\
\hline \multirow{2}{*}{$\beta_{6}$} & $\mathrm{JZ}$ & 0.623 & & 0.045 & & \\
\hline & & {$[5.858]^{* *}$} & & [1.510] & & \\
\hline$\beta_{7}$ & JI & $\begin{array}{c}0.510 \\
{[4.911]^{* *}}\end{array}$ & & $\begin{array}{c}-0.003 \\
{[-0.087]}\end{array}$ & & \\
\hline$\beta_{8}$ & AUTO_KM & $\begin{array}{c}0.041 \\
{[3.996]^{* *}}\end{array}$ & $\begin{array}{c}-0.013 \\
{[-3.598]^{* *}}\end{array}$ & $\begin{array}{c}-0.013 \\
{[-5.316]^{* *}}\end{array}$ & $\begin{array}{c}-0.016 \\
{[-6.348]^{* *}}\end{array}$ & \\
\hline \multirow{2}{*}{$\begin{array}{l}\beta_{9} \\
\beta_{10}\end{array}$} & AUTO_KM*S & $\begin{array}{c}-0.065 \\
{[-5.454]^{* *}}\end{array}$ & $\begin{array}{c}0.012 \\
{[3.446]^{* *}}\end{array}$ & & & \\
\hline & AUTO_KM*I & $\begin{array}{c}-0.046 \\
{[-4150] * * *}\end{array}$ & $\begin{array}{l}-0.006 \\
-12466\end{array}$ & & & \\
\hline \multirow{2}{*}{$\beta_{11}$} & AUTO KM*Z & $\begin{array}{r}{[-.117]} \\
-0.049\end{array}$ & $\begin{array}{l}{[-1.2+0]} \\
-0.001\end{array}$ & & & \\
\hline & & {$[-4.479]^{* *}$} & {$[-0.454]$} & & & \\
\hline \multirow{2}{*}{$\beta_{12}$} & AUTO_KM*J & -0.055 & -0.003 & & & \\
\hline & & {$[-4.588]^{* *}$} & {$[-0.722]$} & & & \\
\hline \multirow{2}{*}{$\beta_{13}$} & AUTO_KM*SI & -0.071 & -0.020 & & & \\
\hline & AUTO KM*JZ & $\begin{array}{c}{[-2.190]^{*}} \\
-0.065\end{array}$ & $\begin{array}{c}{[-2.401]^{*}} \\
-0.001\end{array}$ & & & \\
\hline$\beta_{14}$ & & $\begin{array}{c}-0.005 \\
{[-5.987]^{* *}}\end{array}$ & $\begin{array}{c}-0.001 \\
{[-0.172]}\end{array}$ & & & \\
\hline$\beta_{15}$ & AUTO_KM*JI & $\begin{array}{c}-0.059 \\
{[-4.842]^{* *}}\end{array}$ & $\begin{array}{c}-0.007 \\
{[-1.649]}\end{array}$ & & & \\
\hline$\beta_{16}$ & DCRNOMEREC & $\begin{array}{c}-0.064 \\
{[-2.144]^{*}}\end{array}$ & $\begin{array}{c}-0.081 \\
{[-2.857]^{* *}}\end{array}$ & $\begin{array}{c}-0.081 \\
{[-2.873]^{* *}}\end{array}$ & $\begin{array}{c}-0.030 \\
{[-1.276]}\end{array}$ & $\begin{array}{c}-0.088 \\
{[-4.265]^{* *}}\end{array}$ \\
\hline \multirow{2}{*}{$\beta_{17}$} & DDUBRAVA & -0.286 & -0.245 & -0.254 & -0.281 & -0.356 \\
\hline & & {$[-7.769]^{* *}$} & {$[-6.133]^{* *}$} & {$[-7.353]^{* *}$} & {$[-9.642]^{* *}$} & {$[-13.400]^{* *}$} \\
\hline \multirow{2}{*}{$\beta_{18}$} & DGORNJI_MEDV & 0.004 & 0.043 & 0.014 & 0.068 & 0.068 \\
\hline & & {$[0.125]$} & {$[1.735]$} & {$[0.512]$} & {$[2.759] * *$} & {$[2.755]^{* *}$} \\
\hline \multirow{2}{*}{$\beta_{19}$} & DMAKSIMIR & -0.078 & -0.065 & -0.073 & -0.043 & -0.060 \\
\hline & & {$[-2.948]^{* *}$} & {$[-2.737]^{* *}$} & {$[-2.851]^{* *}$} & {$[-2.092]^{*}$} & {$[-2.920]^{* *}$} \\
\hline
\end{tabular}


Nastavak tablice 5.

\begin{tabular}{|c|c|c|c|c|c|c|}
\hline & Model: & Model 1 & Model 2 & Model 3 & Model 4 & Model 5 \\
\hline & Dep. Var: & \multicolumn{5}{|c|}{ LCIJENA2 } \\
\hline \multirow{2}{*}{$\beta_{20}$} & DNOVIZG & -0.225 & -0.200 & -0.224 & -0.201 & -0.268 \\
\hline & & {$[-7.202]^{* *}$} & {$[-7.386]^{* *}$} & {$[-9.181]^{* *}$} & {$[-8.612]^{* *}$} & {$[-13.652]^{* *}$} \\
\hline \multirow{2}{*}{$\beta_{21}$} & DPESCENICA & -0.182 & -0.166 & -0.178 & -0.184 & -0.214 \\
\hline & & {$[-6.735]^{* *}$} & {$[-6.269]^{* *}$} & {$[-6.933] * *$} & {$[-7.786]^{* *}$} & {$[-9.341]^{* *}$} \\
\hline \multirow{2}{*}{$\beta_{22}$} & DPODSLJEME & -0.140 & -0.135 & -0.147 & -0.072 & -0.104 \\
\hline & & {$[-4.247]^{* *}$} & {$[-4.382]^{* *}$} & {$[-4.585]^{* *}$} & {$[-2.840]^{* *}$} & {$[-4.239]^{* *}$} \\
\hline \multirow{2}{*}{$\beta_{23}$} & DPODSUSED & -0.230 & -0.190 & -0.184 & -0.172 & -0.286 \\
\hline & & {$[-6.438]^{* *}$} & {$[-5.565]^{* *}$} & {$[-5.569]^{* *}$} & {$[-5.565]^{* *}$} & {$[-12.440]^{* *}$} \\
\hline \multirow{2}{*}{$\beta_{24}$} & DSESVETE & -0.442 & -0.351 & -0.376 & -0.393 & -0.510 \\
\hline & & {$[-8.262]^{* *}$} & {$[-4.661]^{* *}$} & {$[-7.038]^{* *}$} & {$[-7.570]^{* *}$} & {$[-13.421] * *$} \\
\hline \multirow{2}{*}{$\beta_{25}$} & DSTENJEVEC & -0.239 & -0.216 & -0.227 & -0.199 & -0.305 \\
\hline & & {$[-7.809]^{* *}$} & {$[-7.681]^{* *}$} & {$[-7.975] * *$} & {$[-7.389]^{* *}$} & {$[-15.119]^{* *}$} \\
\hline \multirow{2}{*}{$\beta_{26}$} & DTRESNJEVKA & -0.160 & -0.119 & -0.143 & -0.104 & -0.160 \\
\hline & & {$[-5.414]^{* *}$} & {$[-5.170]^{* *}$} & {$[-5.596]^{* *}$} & {$[-4.940]^{* *}$} & {$[-8.788]^{* *}$} \\
\hline \multirow{2}{*}{$\beta_{27}$} & DTRNJE & -0.115 & -0.099 & -0.112 & -0.103 & -0.126 \\
\hline & & {$[-4.519]^{* *}$} & {$[-3.950] * *$} & {$[-4.495]^{* *}$} & {$[-4.473]^{* *}$} & {$[-5.617]^{* *}$} \\
\hline \multirow{2}{*}{$\beta_{28}$} & DOSTALO & 0.143 & 0.170 & 0.134 & 0.127 & 0.057 \\
\hline & & {$[0.824]$} & [1.004] & {$[0.802]$} & {$[0.689]$} & {$[0.286]$} \\
\hline$\beta_{29}$ & M2 & $\begin{array}{c}0.000 \\
{[1.000]}\end{array}$ & $\begin{array}{c}0.000 \\
{[1.119]}\end{array}$ & $\begin{array}{c}0.000 \\
{[0.882]}\end{array}$ & $\begin{array}{c}0.000 \\
{[1.719]}\end{array}$ & $\begin{array}{c}0.001 \\
{[1.933]}\end{array}$ \\
\hline \multirow{2}{*}{$\beta_{30}$} & SOBE & -0.013 & -0.013 & -0.012 & -0.015 & -0.018 \\
\hline & & {$[-1.901]$} & {$[-1.840]$} & {$[-1.725]$} & {$[-2.177]^{*}$} & {$[-2.662]^{* *}$} \\
\hline \multirow{2}{*}{$\beta_{31}$} & KAT & -0.003 & -0.003 & -0.003 & -0.004 & -0.003 \\
\hline & & {$[-1.484]$} & {$[-1.634]$} & {$[-1.464]$} & {$[-1.813]$} & {$[-1.655]$} \\
\hline \multirow{2}{*}{$\beta_{32}$} & NOVOGRADNJA & 0.092 & 0.088 & 0.090 & 0.090 & 0.086 \\
\hline & & {$[9.775]^{* *}$} & {$[9.342]^{* *}$} & {$[9.482]^{* *}$} & {$[9.131]^{* *}$} & {$[8.388]^{* *}$} \\
\hline \multirow{2}{*}{$\beta_{33}$} & BALKON & 0.007 & 0.005 & 0.005 & 0.009 & 0.006 \\
\hline & & {$[0.784]$} & [0.589] & {$[0.574]$} & [0.911] & {$[0.603]$} \\
\hline \multirow{2}{*}{$\beta_{34}$} & LOGGIA & 0.034 & 0.031 & 0.032 & 0.033 & 0.031 \\
\hline & & {$[3.546]^{* *}$} & {$[3.156]^{* *}$} & {$[3.234]^{* *}$} & {$[3.294]^{* *}$} & {$[3.024]^{* *}$} \\
\hline \multirow{2}{*}{$\beta_{35}$} & PLIN & 0.032 & 0.034 & 0.035 & 0.036 & 0.039 \\
\hline & & {$[2.666]^{* *}$} & {$[2.812]^{* *}$} & {$[2.955]^{* *}$} & {$[2.951]^{* *}$} & {$[3.175]^{* *}$} \\
\hline \multirow{2}{*}{$\beta_{36}$} & LIFT & 0.056 & 0.058 & 0.058 & 0.051 & 0.057 \\
\hline & & {$[5.449]^{* *}$} & {$[5.604]^{* *}$} & {$[5.647]^{* *}$} & {$[5.063]^{* *}$} & {$[5.553]^{* *}$} \\
\hline \multirow[t]{2}{*}{$\beta_{37}$} & NUM2003 & 0.071 & 0.071 & 0.071 & 0.085 & 0.084 \\
\hline & & [1.802] & [1.912] & {$[1.863]$} & {$[2.127]^{*}$} & {$[2.080]^{*}$} \\
\hline \multirow{2}{*}{$\beta_{38}$} & NUM2004 & 0.140 & 0.099 & 0.109 & 0.138 & 0.109 \\
\hline & & {$[3.267]^{* *}$} & {$[2.006]^{*}$} & {$[2.467]^{*}$} & {$[3.385]^{* *}$} & {$[2.216]^{*}$} \\
\hline \multirow[t]{2}{*}{$\beta_{39}$} & NUM2005 & 0.260 & 0.254 & 0.259 & 0.254 & 0.246 \\
\hline & & {$[5.266]^{* *}$} & {$[4.880]^{* *}$} & {$[5.161]^{* *}$} & {$[4.334]^{* *}$} & {$[3.909]^{* *}$} \\
\hline \multirow[t]{2}{*}{$\beta_{40}$} & NUM2006 & 0.479 & 0.473 & 0.472 & 0.480 & 0.472 \\
\hline & & {$[26.696]^{* *}$} & {$[26.262]^{* *}$} & {$[26.417]^{* *}$} & {$[26.871]^{* *}$} & {$[26.020]^{* *}$} \\
\hline \multirow[t]{2}{*}{$\beta_{41}$} & NUM2007 & 0.607 & 0.597 & 0.600 & 0.603 & 0.592 \\
\hline & & {$[31.873]^{* *}$} & {$[31.778]^{* *}$} & {$[32.409]^{* *}$} & {$[32.141]^{* *}$} & {$[31.004]^{* *}$} \\
\hline
\end{tabular}


T. SLIŠKOVIĆ, J. TICA: Značaj udaljenosti u hedonističkom modelu određivanja cijena stanova u Zagrebu EKONOMSKI PREGLED, 70 (5) 677-705 (2019)

Nastavak tablice 5.

\begin{tabular}{|c|c|c|c|c|c|c|}
\hline & Model: & Model 1 & Model 2 & Model 3 & Model 4 & Model 5 \\
\hline \multirow{3}{*}{$\beta_{42}$} & Dep. Var: & \multicolumn{5}{|c|}{ LCIJENA2 } \\
& NUM2008 & 0.515 & 0.511 & 0.510 & 0.517 & 0.517 \\
$\beta_{43}$ & & {$[14.803]^{* *}$} & {$[14.343]^{* *}$} & {$[14.769]^{* *}$} & {$[14.598]^{* *}$} & {$[14.502]^{* *}$} \\
& NUM2010 & 0.422 & 0.415 & 0.417 & 0.420 & 0.409 \\
$\beta_{44}$ & & {$[31.888]^{* *}$} & {$[31.221]^{* *}$} & {$[31.669]^{* *}$} & {$[31.179]^{* *}$} & {$[29.867]^{* *}$} \\
& \multirow{3}{*}{$\beta_{45}$} & 0.370 & 0.365 & 0.367 & 0.370 & 0.360 \\
& NUM2011 & {$[25.273]^{* *}$} & {$[24.549]^{* *}$} & {$[25.249]^{* *}$} & {$[24.730]^{* *}$} & {$[23.538]^{* *}$} \\
$\beta_{46}$ & NUM2012 & 0.333 & 0.327 & 0.329 & 0.336 & 0.330 \\
& & {$[15.700]^{* *}$} & {$[15.259]^{* *}$} & {$[15.526]^{* *}$} & {$[15.772]^{* *}$} & {$[15.297]^{* *}$} \\
& NUM2013 & 0.245 & 0.244 & 0.244 & 0.246 & 0.238 \\
& & {$[7.620]^{* *}$} & {$[7.520]^{* *}$} & {$[7.598]^{* *}$} & {$[7.527]^{* *}$} & {$[7.251]^{* *}$} \\
\hline \multirow{3}{*}{} & Observations: & 1933 & 1933 & 1933 & 1933 & 1933 \\
& R-squared: & $\mathbf{0 . 5 9 8}$ & $\mathbf{0 . 5 8 4}$ & $\mathbf{0 . 5 9 0}$ & $\mathbf{0 . 5 7 5}$ & $\mathbf{0 . 5 6 4}$ \\
& F-statistic: & 61.101 & 68.258 & 69.991 & 80.186 & 79.366 \\
\hline
\end{tabular}

Napomena: U zagradama su navedene vrijednosti t-statistike. Zvjezdice uz t-statistiku upućuju na odbacivanje nulte hipoteze o neznačajnosti varijable u modelu na razini signifikantnosti od $1 \%(* *)$ i $5 \%(*)$.

Iz tablice rezultata je razvidno kako najveći dio zaključaka dobivenih pri procjeni prethodnih modela s traženim cijenama ostaje nepromijenjen kada se kao zavisna varijabla koriste postignute cijene. Predznaci parametara i njihova statistička značajnost uz lokacijske i vremenske varijable su nepromijenjeni i njihova interpretacija je gotovo identična u odnosu na rezultate prikazane u tablici 3. Manje razlike postoje isključivo u vrijednostima samih koeficijenata. Razlike u statističkoj značajnosti procijenjenih parametara između polaznih modela s različitim vrstama cijena postoje samo u skupini internih karakteristika. U najširem modelu s postignutim cijenama varijable površina i kat nisu značajni za objašnjavanje cijene, dok postojanje lođe ima pozitivne učinke na istu. Usporedba najšireg modela s postignutim cijenama i njegovih užih oblika pomoću skupnog Waldovog testa (Tablica 6) je potvrdila zaključke iznesene na temelju modela s traženim cijenama - model koji uključuje varijable udaljenosti i strana svijeta potpuniji je i bolje prilagođen postojećim podacima od njegovih užih oblika i onih koji su do sada korišteni u praksi. 
Tablica 6:

\section{REZULTATI PROVEDENOG WALDOVOG TESTA ZA SKUPINE VARIJABLI U MODELU S POSTIGNUTIM CIJENAMA}

\begin{tabular}{|l|c|}
\hline & $\begin{array}{c}\text { Wald test } \\
\text { p-value }\end{array}$ \\
\hline$\beta_{1}=\beta_{2}=\beta_{3}=\beta_{4}=\beta_{5}=\beta_{6}=\beta_{7}=0$ & 0.000000 \\
\hline$\beta_{9}=\beta_{10}=\beta_{11}=\beta_{12}=\beta_{13}=\beta_{14}=\beta_{15}=0$ & 0.000000 \\
\hline$\beta_{1}=\beta_{2}=\beta_{3}=\beta_{4}=\beta_{5}=\beta_{6}=\beta_{7}=\beta_{9}=\beta_{10}=\beta_{11}=\beta_{12}=\beta_{13}=\beta_{14}=\beta_{15}=0$ & 0.000000 \\
\hline$\beta_{1}=\beta_{2}=\beta_{3}=\beta_{4}=\beta_{5}=\beta_{6}=\beta_{7}=\beta_{8}=\beta_{9}=\beta_{10}=\beta_{11}=\beta_{12}=\beta_{13}=\beta_{14}=\beta_{15}=0$ & 0.000000 \\
\hline
\end{tabular}

Posljednji korak u analizi je bilo formiranje dodatnog modela, ali s nešto manjim brojem nezavisnih varijabli. Obzirom da su rezultati pokazali kako je najširi hedonički model u obje procijenjene varijante najbolje prilagođen postojećim podacima, sljedeći korak je bio pokušaj redukcije regresora u modelu na način da se grupiraju one strane svijeta (osim sjeverozapada koji je po pretpostavci različit od ostalih) koje međusobno nisu statistički značajno različite. Kako bi se ispitalo imaju li neke od preostalih 7 strana svijeta međusobno iste konstantne članove, ili pak iste nagibe regresijskih pravaca, provedeni su pojedinačni Waldovi testovi. S obzirom na činjenicu da ne postoje znatne razlike između hedoničkih modela s traženim i postignutim cijenama i uzimajući u obzir veći broj podataka o traženim cijenama, pojedinačni Waldovi testovi su provedeni samo na temelju modela s traženim cijenama. Rezultati Waldovih testova u kojem su postavljena ograničenja na parametre koji opisuju razlike u konstantnim članovima s obzirom na strane svijeta su dani u tablici 7, dok su rezultati testa postavljanja ograničenja na interakcijske dummy varijable prikazane u tablici 8 . 


\section{Tablica 7:}

REZULTATI WALDOVIH TESTOVA POSTAVLJANJA OGRANIČENJA NA PARAMETRE VARIJABLI STRANA SVIJETA KOJE OPISUJU RAZLIKE U KONSTANTNIM ČLANOVIMA

\begin{tabular}{|c|c|c|}
\hline H0 & Wald test p-value & \\
\hline$\beta(1)=\beta(2)$ & 0.000 & $* *$ \\
\hline$\beta(1)=\beta(3)$ & 0.002 & $* *$ \\
\hline$\beta(1)=\beta(4)$ & 0.387 & \\
\hline$\beta(1)=\beta(5)$ & 0.513 & \\
\hline$\beta(1)=\beta(6)$ & 0.450 & \\
\hline$\beta(1)=\beta(7)$ & 0.043 & $*$ \\
\hline$\beta(2)=\beta(3)$ & 0.349 & \\
\hline$\beta(2)=\beta(4)$ & 0.001 & $* *$ \\
\hline$\beta(2)=\beta(5)$ & 0.889 & \\
\hline$\beta(2)=\beta(6)$ & 0.000 & $* *$ \\
\hline$\beta(2)=\beta(7)$ & 0.008 & $* *$ \\
\hline$\beta(3)=\beta(4)$ & 0.038 & $*$ \\
\hline$\beta(3)=\beta(5)$ & 0.977 & \\
\hline$\beta(3)=\beta(6)$ & 0.000 & $* *$ \\
\hline$\beta(3)=\beta(7)$ & 0.175 & \\
\hline$\beta(4)=\beta(5)$ & 0.638 & \\
\hline$\beta(4)=\beta(6)$ & 0.142 & \\
\hline$\beta(4)=\beta(7)$ & 0.323 & \\
\hline$\beta(5)=\beta(6)$ & 0.422 & \\
\hline$\beta(5)=\beta(7)$ & 0.775 & \\
\hline$\beta(6)=\beta(7)$ & 0.012 & $*$ \\
\hline
\end{tabular}

Napomena: Zvjezdice upućuju na odbacivanje nulte hipoteze na razini signifikantnosti od $1 \%(* *)$ i $5 \%(*)$. 


\section{Tablica 8:}

\section{REZULTATI WALDOVIH TESTOVA POSTAVLJANJA OGRANIČENJA NA PARAMETRE INTERAKCIJSKIH VARIJABLI KOJE OPISUJU RAZLIKE U NAGIBIMA REGRESIJSKIH PRAVACA}

\begin{tabular}{|c|c|c|}
\hline HO & Wald test $p$-value & \\
\hline$\beta(9)=\beta(10)$ & 0.070 & \\
\hline$\beta(9)=\beta(10)$ & 0.087 & \\
\hline$\beta(9)=\beta(12)$ & 0.117 & \\
\hline$ß(9)=ß(13)$ & 0.748 & \\
\hline$\beta(9)=\beta(14)$ & 0.323 & \\
\hline$\beta(9)=\beta(15)$ & 0.237 & \\
\hline$\beta(10)=ß(11)$ & 0.758 & \\
\hline$\beta(10)=\beta(12)$ & 0.001 & $* *$ \\
\hline$B(10)=\beta(13)$ & 0.417 & \\
\hline$\beta(10)=ß(14)$ & 0.001 & $* *$ \\
\hline$B(10)=ß(15)$ & 0.003 & $* *$ \\
\hline$\beta(11)=\beta(12)$ & 0.001 & $* *$ \\
\hline$\beta(11)=\beta(13)$ & 0.454 & \\
\hline$B(11)=ß(14)$ & 0.000 & $* *$ \\
\hline$\beta(11)=\beta(15)$ & 0.005 & $* *$ \\
\hline$B(12)=B(13)$ & 0.858 & \\
\hline$B(12)=ß(14)$ & 0.375 & \\
\hline$\beta(12)=\beta(15)$ & 0.617 & \\
\hline$\beta(13)=\beta(14)$ & 0.936 & \\
\hline$B(13)=B(15)$ & 0.976 & \\
\hline$\beta(14)=\beta(15)$ & 0.691 & \\
\hline
\end{tabular}

Napomena: Zvjezdice upućuju na odbacivanje nulte hipoteze na razini signifikantnosti od $1 \%(* *)$ i $5 \%(*)$.

$\mathrm{Na}$ temelju provedenih Waldovih testova bilo je moguce iskonstruirati parove, odnosno skupove strana svijeta koje međusobno imaju jednake konstantne članove i jednake nagibe regresijskih pravaca. Prema dobivenim rezultatima, međusobno jednake konstantne članove imaju strane svijeta:

- Jug, Zapad i Jugoistok

- Sjever i Jugozapad

- Sjeveroistok i Istok 
Jednake nagibe regresijskih pravaca imaju strane svijeta:

- Jugozapad, Jug i Jugoistok

- Sjever, Sjeveroistok, Istok i Zapad

Provedba Waldovog testa je pokazala da se za sve kombinacije ne može odbaciti nulta hipoteza o jednakosti navedenih skupina parametara (Tablica 9).

Tablica 9:

\section{WALDOV TEST OGRANIČENJA NA ODABRANE SKUPINE PARAMETARA}

\begin{tabular}{|c|c|}
\hline H0 & Wald test p-value \\
\hline$\beta(4)=\beta(3)=\beta(7)$ & 0.115000 \\
\hline$\beta(2)=\beta(5)$ & 0.888800 \\
\hline$\beta(6)=\beta(1)$ & 0.449800 \\
\hline$\beta(9)=\beta(13)=\beta(10)=\beta(11)$ & 0.212200 \\
\hline$\beta(14)=\beta(12)=\beta(15)$ & 0.674000 \\
\hline
\end{tabular}

Na temelju dobivenih rezultata pojedine su strane svijeta grupirane te je procijenjen novi hedonički model traženih cijena (model 6 u Tablici 3). Važno je istaknuti taj model ne predstavlja posebni oblik najšireg hedoničkog modela traženih cijena, stoga ih nije moguće međusobno uspoređivati skupnim Waldovim testom. Model 6 predstavlja zaseban oblik hedoničkog modela u kojem su određene strane svijeta grupirane prema rezultatima provedenih Wald testova. Pri interpretaciji parametara procijenjenih unutar modela 6 gotovo da nema razlike u odnosu na najširi hedonički model s traženim cijenama. Može se, i u slučaju interpretacije modela 6, potvrditi specifičnost Sjeverozapada. Skupine Jug, Zapad i Jugoistok; Sjever i Jugozapad te potom Sjeveroistok i Istok imaju statistički značajne veće prosječne cijene na nultom kilometru od Sjeverozapada. Također, skupno gledano, područja Jugozapada, Juga i Jugoistoka te Sjevera, Sjeveroistoka, Istoka i Zapada, za razliku od specifičnog Sjeverozapada, imaju statistički značajno različite i negativne nagibe regresijskih pravaca.

Obzirom da su svi koeficijenti uz varijable udaljenosti i strana svijeta statistički značajni, može se još jednom potvrditi zaključak kako uključivanje tih varijabli u hedoničke modele dovodi do očekivanih i logičnih rezultata koji su u potpunosti u skladu s realnošću. Kako je potvrđeno da njihovo uključivanje u model doprinosi boljoj prilagođenosti modela stvarnim podacima, ne bi smjeli biti zanemarivani u daljnjim istraživanjima odrednica cijena stambenog prostora koja se temelje na uporabi hedoničkih modela. 


\section{ZAKLJUČAK}

Cilj ovoga istraživanja bio je ispitati važnost udaljenosti od centra u objašnjavanju devijacija u cijenama stanova na zagrebačkom stambenom tržištu. Udaljenost je definirana kao prostorna udaljenost u kilometrima koju je potrebno prijeći da se automobilom stigne od promatrane nekretnine do Trga Bana Josipa Jelačića.

Motivacija za uključivanje udaljenosti u vektor varijabli koje objašnjavaju cijene stanova je proizašla prvenstveno iz teoretskih modela prostorne ekonomije koje tradicionalno tretiraju udaljenost kao ključnu varijablu u objašnjavanju trgovinskih tijekova i prostornih aglomeracija ljudi i ekonomske aktivnosti.

Imajući u vidu kako je upravo nedostatak kvalitetnih baza podataka ključna prepreka u evaluaciji utjecaja udaljenosti na cijene stanova, uloženi su značajni napori u nadogradnji i proširivanju baze podataka Burze nekretnina kako bi se mogao kvantificirati utjecaj udaljenosti u vrijednosti stanova.

Rezultati istraživanja su pokazali da prema svim standardnim metodama hedoničke procjene vrijednosti nekretnina udaljenost statistički značajno djeluje na cijene stambenih jedinica. Povrh toga, istraživanje je pokazalo da se i utjecaj udaljenosti razlikuje u ovisnosti na kojoj strani svijeta mjerimo udaljenost nekretnina. Rezultati su se pokazali robusnima na traženim i postignutim cijenama nekretnina.

U kontekstu ekonomske politike ključan doprinos ovoga istraživanja je višeslojan. Prvo, prema Nacionalnom planu reformi, bilo je planirano donošenje Uredbe o masovnoj procjeni vrijednosti nekretnina. Nalazi ovoga istraživanja bi, u toj sferi, mogli pomoći stručnim skupinama u definiranju postupka masovne procjene. Drugo, rezultati ovoga istraživanja trebali bi pomoći i procjeniteljima i procjeniteljskim povjerenstvima, Poreznoj upravi, kao i regulatorima financijskih tržišta u potpunijem razumijevanju zbivanja na tržištima. Treće, rezultati mogu biti korisni i stručnim službama u jedinicama lokalne vlasti pri definiranju veličine i opsega zona koje služe za razrezivanje komunalnog doprinosa i komunalne naknade. Obzirom na činjenicu kako svako lokalno tržište ima svoje specifičnosti, preduvjet za ostvarivanje punog efekta ovakvog modeliranja u praksi bi svakako bila baza podataka koja sadrži informacije o prodanim nekretninama na ostalim lokalnim tržištima u Hrvatskoj, čemu se teži u budućnosti.

Ključno ograničenje ovoga istraživanja je prvenstveno veličina baze podataka, kao i kvaliteta samih podataka iz razloga što se radi o pristranom uzroku u kojem dominiraju stanovi prodani putem posrednika na tržištu nekretnina. Navedena činjenica bi trebala implicirati pristranost prema većim cijenama, barem načelno. Korištenje bogatije baze ili eventualno kompletne populacije traženih stanova bi u svakom slučaju značajno unaprijedilo robusnost procjene. Navedeno je vjerojatno i razlog za činjenicu kako se ovdje formuliranim modelom (koji je zapravo najširi 
T. SLIŠKOVIĆ, J. TICA: Značaj udaljenosti u hedonističkom modelu određivanja cijena stanova u Zagrebu EKONOMSKI PREGLED, 70 (5) 677-705 (2019)

do sada prezentiran u domaćoj literaturi) može objasniti manje od $60 \%$ varijacija u traženim i postignutim cijenama stanova na zagrebačkom tržištu. Potpunija baza podataka bi također otvorila prostor za korištenje nekih od složenijih metoda procjene cijena nekretnina kojima bi se nadvladale navedene poteškoće.

\section{Literatura}

- $\quad$ Alonso, W. (1964). Location and Land Use: Toward a General Theory of Land Rent. Cambridge, Massachusetts: Harvard University Press.

- Anselin, L. i Le Gallo, J. (2006). Interpolation of Air Quality Measures in Hedonic House Price Models: Spatial Aspects. Spatial Economic Analysis, 1 (1), str. 31-52. DOI: 10.1080/17421770600661337

- $\quad$ Boras, T. (2013). Udaljenost i dostupnost centra grada kao determinante traženih cijena stambenog prostora. Ekonomski pregled, 64 (6), str. 563-586.

- Botrić, V. i Kordej De Villa, Ž. (23.-27- kolovoz 2005.). Determinants of regional housing market in Croatia. 45th Congress of the European Regional Science Association. Amsterdam.

- $\quad$ Burza nekretnina (2015), interni podaci za razdoblje 2002-2013

- Centar Nekretnina (2015), indeks cijena nekretnina za prosinac 2015

- Dubin, R. (1991). Commuting Patterns and Firm Decentralization. Land Economics, 67(1), str. 15-29. DOI: $10.2307 / 3146482$

- $\quad$ Dubin, R. A. i Sung, C. H. (1987). Spatial Variation in the Price of Housing: Rent Gradients in Non-Monocentric Cities. Urban Studies (24), str. 193-204. DOI: 10.1080/00420988720080331

- $\quad$ Fina, M. H. (2000). Urban Spatial Structure and Household Travel Time. Doktorska disertacija. Virginia Polytechnic Institute and State University.

- $\quad$ Fujita, M., Krugman, P. i Venables, A. (1999). The Spatial Economy: Cities, Regions and International Trade. Cambridge: The MIT Press.

- Giuliano, G. i Small, K. A. (1991). Subcenters in the Los Angeles Region. Regional Science and Urban Economics(21), str. 163-182. DOI: 10.1016/01660462(91)90032-i

- Heikkila et al. (1989). What happened to the CBD-distance gradient?: land values in a policentric city. Environment and Planning A(21), str. 221-232. DOI: doi:10.1068/a210221

- $\quad$ Hill, R. (2011). Hedonic Price Indexes for Housing. OECD Statistics Working Papers, 2011/01. OECD Publishing. DOI: 10.1787/5kghzxpt6g6f-en 
- Huang, B., Wu, B. i Barry, M. (2010). Geographically and temporally weighted regression for modeling spatio-temporal variation in house prices. International Journal of Geographical Information Science(24:3), str. 383-401. DOI: 10.1080/13658810802672469

- Kunovac, D., Đozović, E., Lukinić G. i Pufnik, A. (2008). Primjena hedonističke metode za izračunavanje indeksa cijena nekretnina u Hrvatskoj. Istraživanja(I-20). Zagreb: Hrvatska narodna banka.

- $\quad$ McMillen, D. P. i Redfearn, C. L. (2010). Estimation and hypothesis testing for nonparametric hedonic house price functions. Journal of Regional Science, 50 (3), str. 712-733. DOI: 10.1111/j.1467-9787.2010.00664.x

- Mills, E. S. (1972). Studies in the Structure of the Urban Economy. Baltimore: The Johns Hopkins Press.

- Muth, R. (1969). Cities and Housing. Chicago: University of Chicago Press.

- Ottensmann, J. R., Payton, S. i Man, J. (2008). Urban Location and Housing Prices within a Hedonic Model. The Journal of Regional Analysis and Policy, 38(1), str. 19-35.

- $\quad$ Peterson, S. i Flanagan, A. B. (2009). Neural Network Hedonic Pricing Models in Mass Real Estate Appraisal. Journal of Real Estate Research, 31 (2), str. 147-164.

- Slišković, T. i Tica, J. (2016). Prostorna elastičnost traženih cijena stanova na stambenom tržištu Grada Zagreba. Ekonomska misao i praksa: časopis Sveučilišta u Dubrovniku, God. 25, Br. 2, str. 23-44.

- Small, K. A. i Song, S. (1992). Wasteful' Commuting: A Resolution. Journal of Political Economy, 100(4), str. 888-898. DOI: 10.1086/261844

- Vlada RH (2017) Nacionalni program reformi 2017., https://vlada.gov.hr/

- Von Thünen, J. H. (1826). The Isolated State (Pretiskano 1966. izd.). New York: Pergamon Press.

- Walacik, M., Cellmer, R. i Źróbek, S. (2013). Mass Appraisal - International Background, Polish Solutions and Proposal of new Methods Application. Geodetski list(67 (90)(4)), str. 255-269.

- Wooldridge, J. M. (2013). Introductory Econometrics: A Modern Approach (Fifth Edition). South-Western, Cengage Learning.

- Worzala, E., Lenk, M. i Silva, A. (1995). An exploration of neural networks and its application to real estate valuation. The Journal of Real Estate Research, 10 (2), str. 185-201.

- Yiu, C. Y. i Tam, C. S. (2004). The estimation of housing price gradients: A comparison of different approaches applied in Hong Kong. International 
Conference: Adequate\&Affordable Housing for all. Toronto: Centre for Urban and Community Studies, University of Toronto.

\author{
THE IMPORTANCE OF DISTANCE IN HEDONIC HOUSING PRICE MODEL \\ - THE CASE OF ZAGREB
}

\begin{abstract}
Summary
The goal of this paper is to estimate the effect of distance from city center on housing prices in Zagreb within the hedonic model. Presented model is the first in Croatian literature which at the same time includes distance, other locational variables, internal characteristics and the effect of the time of transaction. This research differs from the current practice in Croatia in the fact that, up to now, location of dwelling was mainly approximated with city district, neighborhood etc. Estimation of distance effects, along with other locational variables, was performed within hedonic models of offer and achieved housing prices. Results show that the distance from the city center and the variables which describe the location of dwelling on certain side of world are statistically significant for explaining prices in the Zagreb housing market. Furthermore, their inclusion in the hedonic model improves its goodness of fit compared to previous models constructed for Croatian housing markets.
\end{abstract}

Key words: distance, city center, hedonic estimation, housing prices 